NASA/TM—2009-215662

\title{
Simplified Approach to Predicting Rough Surface Transition
}

Robert J. Boyle

Glenn Research Center, Cleveland, Ohio

Matthias Stripf

Universitat Karlsruhe, Karlsruhe, Germany 


\section{NASA STI Program . . . in Profile}

Since its founding, NASA has been dedicated to the advancement of aeronautics and space science. The NASA Scientific and Technical Information (STI) program plays a key part in helping NASA maintain this important role.

The NASA STI Program operates under the auspices of the Agency Chief Information Officer. It collects, organizes, provides for archiving, and disseminates NASA's STI. The NASA STI program provides access to the NASA Aeronautics and Space Database and its public interface, the NASA Technical Reports Server, thus providing one of the largest collections of aeronautical and space science STI in the world. Results are published in both non-NASA channels and by NASA in the NASA STI Report Series, which includes the following report types:

- TECHNICAL PUBLICATION. Reports of completed research or a major significant phase of research that present the results of NASA programs and include extensive data or theoretical analysis. Includes compilations of significant scientific and technical data and information deemed to be of continuing reference value. NASA counterpart of peer-reviewed formal professional papers but has less stringent limitations on manuscript length and extent of graphic presentations.

- TECHNICAL MEMORANDUM. Scientific and technical findings that are preliminary or of specialized interest, e.g., quick release reports, working papers, and bibliographies that contain minimal annotation. Does not contain extensive analysis.

- CONTRACTOR REPORT. Scientific and technical findings by NASA-sponsored contractors and grantees.
- CONFERENCE PUBLICATION. Collected papers from scientific and technical conferences, symposia, seminars, or other meetings sponsored or cosponsored by NASA.

- SPECIAL PUBLICATION. Scientific, technical, or historical information from NASA programs, projects, and missions, often concerned with subjects having substantial public interest.

- TECHNICAL TRANSLATION. Englishlanguage translations of foreign scientific and technical material pertinent to NASA's mission.

Specialized services also include creating custom thesauri, building customized databases, organizing and publishing research results.

For more information about the NASA STI program, see the following:

- Access the NASA STI program home page at http://www.sti.nasa.gov

- E-mail your question via the Internet to help@ sti.nasa.gov

- Fax your question to the NASA STI Help Desk at $443-757-5803$

- Telephone the NASA STI Help Desk at 443-757-5802

- Write to: NASA Center for AeroSpace Information (CASI) 7115 Standard Drive Hanover, MD 21076-1320 
NASA/TM-2009-215662

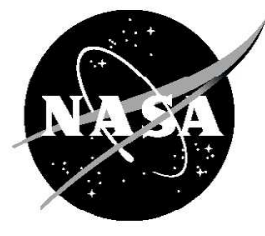

\section{Simplified Approach to Predicting Rough Surface Transition}

Robert J. Boyle

Glenn Research Center, Cleveland, Ohio

Matthias Stripf

Universitat Karlsruhe, Karlsruhe, Germany

Prepared for the

Gas Turbine Technical Congress and Exposition (Turbo Expo 2008) sponsored by the American Society of Mechanical Engineers Berlin, Germany, June 9-13, 2008

National Aeronautics and

Space Administration

Glenn Research Center Cleveland, Ohio 44135 
This work was sponsored by the Fundamental Aeronautics Program at the NASA Glenn Research Center.

Level of Review: This material has been technically reviewed by technical management.

Available from

NASA Center for Aerospace Information

7115 Standard Drive

Hanover, MD 21076-1320
National Technical Information Service 5285 Port Royal Road Springfield, VA 22161

Available electronically at http://gltrs.grc.nasa.gov 


\title{
Simplified Approach to Predicting Rough Surface Transition
}

\author{
Robert J. Boyle \\ National Aeronautics and Space Administration \\ Glenn Research Center \\ Cleveland, Ohio 44135 \\ Matthias Stripf \\ Universitat Karlsruhe \\ Karlsruhe, Germany
}

\begin{abstract}
Turbine vane heat transfer predictions are given for smooth and rough vanes where the experimental data show transition moving forward on the vane as the surface roughness physical height increases. Consistent with smooth vane heat transfer, the transition moves forward for a fixed roughness height as the Reynolds number increases. Comparisons are presented with published experimental data. Some of the data are for a regular roughness geometry with a range of roughness heights, Reynolds numbers, and inlet turbulence intensities. The approach taken in this analysis is to treat the roughness in a statistical sense, consistent with what would be obtained from blades measured after exposure to actual engine environments. An approach is given to determine the equivalent sand grain roughness from the statistics of the regular geometry. This approach is guided by the experimental data. A roughness transition criterion is developed, and comparisons are made with experimental data over the entire range of experimental test conditions. Additional comparisons are made with experimental heat transfer data, where the roughness geometries are both regular as well as statistical. Using the developed analysis, heat transfer calculations are presented for the second stage vane of a high pressure turbine at hypothetical engine conditions.
\end{abstract}

\section{Nomenclature}

$\begin{array}{ll}A^{+} & \text {Near wall damping coefficient } \\ C & \text { Modeling constant } \\ C_{\mathbf{x}} & \text { Axial chord } \\ C_{\mathrm{f}} / 2 & \text { Friction coefficient } \\ d & \text { Base diameter } \\ H^{+} & \text {Normalized roughness height } \\ h & \text { Heat transfer coefficient } \\ K & \text { Acceleration parameter } \\ k & \text { Physical roughness height } \\ k_{\mathrm{S}} & \text { Equivalent sand grain roughness } \\ M & \text { Mach number } \\ n & \text { Number of points in roughness calculation } \\ N & \text { Spot production parameter } \\ N u & \text { Nusselt number } \\ P & \text { Pressure }\end{array}$

$\begin{array}{ll}p & \text { Pitch } \\ R_{\mathrm{a}} & \text { Absolute roughness height } \\ R_{\mathrm{RMS}} & \text { Root mean square roughness height } \\ R e & \text { Reynolds number } \\ R e_{1} & \text { Unit Reynolds number } \\ S & \text { Surface distance } \\ S_{\mathrm{k}} & \text { Skewness } \\ S t & \text { Stanton number } \\ T u & \text { Turbulence intensity } \\ U & \text { Velocity } \\ Y & \text { Loss coefficient } \\ y & \text { Measured height } \\ \bar{y} & \text { Distance from surface } \\ \Delta y & \text { Average height } \\ \Delta y+ & \text { Increase in mixing length due to roughness } \\ \theta & \text { Normalized value for } \Delta y \\ \kappa & \text { Momentum thickness } \\ \mu & \text { Mixing length constant } \\ \mu_{\mathrm{t}, \mathrm{i}} & \text { Dynamic viscosity } \\ \rho & \text { Inner region eddy viscosity }\end{array}$

$\underline{\text { Subscripts }}$

\begin{tabular}{lll}
\hline 2 & & Vane exit \\
FS & & Local freestream \\
IN & & Vane inlet \\
RLM & & Relaminarization \\
ROUGH & & Rough \\
SMOOTH & & Smooth \\
SK & & Skewness \\
SL & & Length \\
ST & & Transition start \\
t & Total
\end{tabular}

\section{INTRODUCTION}

Surface roughness adversely affects turbomachinery performance by increasing external heat transfer, and by increasing loss. Measured surface roughness for in service blades show a high degree of variability. It is useful to the designer to have an estimate of the effects of surface roughness on both heat transfer and aerodynamic performance. Data show that as the roughness height progressively increases, turbine vane transition moves forward on 
both the suction and pressure surfaces of the vane. Data, such as those of Arts[1], show that a smooth vane can have laminar flow over much of the vane at moderate Reynolds numbers, even with relatively high inlet turbulence. When the boundary layer is not forced to be turbulent due to film cooling, understanding the interaction of surface roughness and transition is important. The change in blade surface heat transfer with transition is a very good indicator of transition start and length. Tests of a solid high pressure turbine vane are therefore valuable, even if the vane is film cooled when installed in an engine. Transition is typically not an issue for the first turbine stage, since the blades are generally film cooled. Arts[2] has shown that just the presence of film cooling holes causes transition to turbulent flows on the blade surfaces. In later stages, film cooling may not be used, and the Reynolds numbers are lower. Heat transfer may remain a concern if blades have only internal cooling. Hourmouziadis[3] showed nearly an order of magnitude decrease in Reynolds numbers between the high pressure turbine inlet and the last low pressure turbine stage. Predicting the performance of low pressure turbines is highly dependent on understanding transition, especially at cruise conditions, where laminar separation can cause severe loss penalties.

Surface roughness generally adversely affects blade row aerodynamic efficiency. Kind et al.[4], Boynton et al.[5], Bammert and Stanstede[6,7] reported decreases in turbine efficiencies of up to several points due to surface roughness. Abuaf et al.[8] and Stabe and Liebert[9] showed that just polishing blade surfaces can improve efficiency. On the other hand Harbecke et al.[10] showed that profile loss was not increased until a critical roughness height was reached. Boyle and Senyitko[11] showed that high Reynolds number surface roughness doubled vane loss, but at low Reynolds numbers roughness improved aerodynamic efficiency. Roughness modified the Reynolds number and surface location at which separation occurred. To utilize surface roughness to improve low pressure turbine aerodynamic efficiency requires understanding of the effects of roughness on transition. To predict the efficiency decrement due to roughness at higher Reynolds numbers also requires understanding of the effects of roughness on the surface boundary layers.

There are two approaches to calculating rough surface boundary layers. The first is the Discrete Element Method, and is ideally suited to situations where the roughness geometry is known, and is regular and periodic. This method has been used by a number of researchers, and shown to give accurate results. Taylor et al.[12], Hosni et al.[13], and Stripf et al.[14] used this method to calculate rough surface heat transfer. McClain[15] extended the Discrete Element Model to account for random roughness, and McClain et al.[16] presented friction factor and heat transfer comparisons with data developed using roughness deter- mined from actual blade measurements. The characteristics of measured turbine blade roughness vary widely, and a priori Discrete Element Model calculations need detailed information regarding the roughness characteristics.

The second, and older, approach to calculating rough surface boundary layers is to calculate the equivalent sand grain roughness. Several authors have proposed correlations to obtain the equivalent sand grain roughness. Among these are Sigal and Danberg[17], Dvorak[18], Simpson[19], Dirling[20],van Rij et al.[21], and Waigh and Kind[22]. Common to all these correlations is the requirement that the roughness image or trace be modeled as a roughness geometry, in order to obtain values for projected and windward areas. The correlation of Koch and Smith[23] only uses a statistical value from the roughness trace or image.

The Koch and Smith[23] correlation provides the simplest way of determining the equivalent sand grain roughness from the roughness image. The suitability of this correlation can be determined by using the statistical parameters of regular roughness geometries. A regular roughness geometry is one that is suitable for the Discrete Element Method. It was found that better agreement with the experimental data was achieved by a modification to the Koch and Smith correlation.

There are four parts to the work presented herein. The first determines a correlation for the equivalent sand grain roughness, $k_{\mathrm{S}}$, that is consistent with the experimental data of Stripf et al.[24]. The second part determines modifications to transition start and relaminarization criteria to yield heat transfer predictions consistent with the same experimental data. The third part compares heat transfer predictions using the proposed modifications with data to determine the applicability of the modeling to other data sets. The fourth part shows heat transfer and aerodynamic loss calculations at a unit Reynolds number consistent with current engine operating conditions. Even though both the determination of the equivalent sand grain roughness and the transition criteria are derived from the same data they are not wholly dependent on each other. If the reader prefers a different method of calculating $k_{\mathrm{S}}$, the coefficients in the transition criteria could be changed to yield the same results with different values for $k_{\mathrm{S}}$.

\section{DISCUSSION of RESULTS}

\section{Equivalent sand grain roughness}

The roughness geometry used in the test of Stripf et al.[24] to measure vane heat transfer coefficients is shown in figure 1. In their tests the height of the truncated cones, as well as the spacing between cones were varied. The dimensions of the roughness geometry is given in Table $I$. For all tests the vane axial and true chords were 53 and 94 $\mathrm{mm}$. Data were obtained for variations in inlet turbulence 
Table I. Dimension of roughness elements

\begin{tabular}{|l|r|r|r|}
\hline Label & $\begin{array}{r}k \\
\mu \mathrm{m}\end{array}$ & $\begin{array}{r}d \\
\mu \mathrm{m}\end{array}$ & $\begin{array}{r}p \\
\mu \mathrm{m}\end{array}$ \\
\hline $\mathrm{r} 10 \mathrm{~m}$ & 10 & 25 & 55 \\
$\mathrm{r} 10 \mathrm{~s}$ & 10 & 25 & 70 \\
$\mathrm{r} 20 \mathrm{~m}$ & 20 & 50 & 110 \\
$\mathrm{r} 20 \mathrm{~s}$ & 20 & 50 & 140 \\
$\mathrm{r} 30 \mathrm{~m}$ & 30 & 75 & 165 \\
$\mathrm{r} 40 \mathrm{~m}$ & 40 & 100 & 220 \\
$\mathrm{r} 40 \mathrm{~s}$ & 40 & 100 & 300 \\
$\mathrm{r} 50 \mathrm{~s}$ & 48 & 100 & 300 \\
$\mathrm{r} 80 \mathrm{~m}$ & 80 & 200 & 440 \\
$\mathrm{r} 80 \mathrm{~s}$ & 80 & 200 & 600 \\
\hline
\end{tabular}

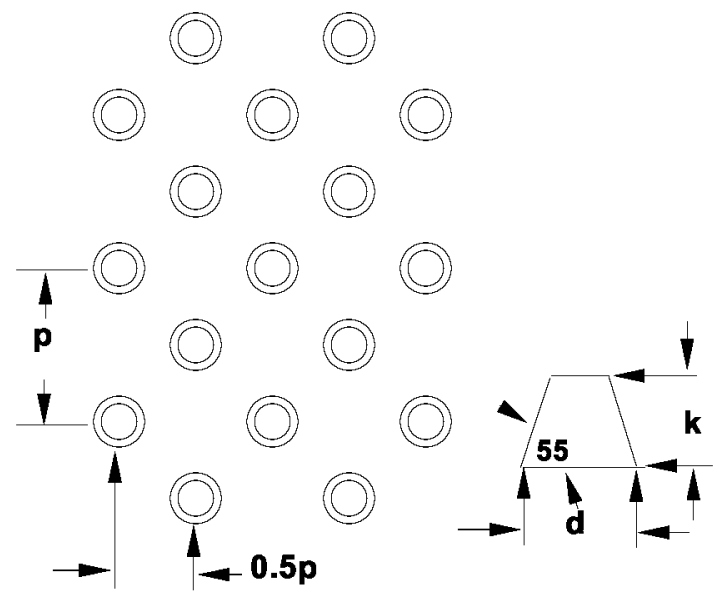

Fig. 1 Arrangement of truncated cone roughness elements.

intensity and Reynolds numbers. Figure 2 shows their measured heat transfer coefficients at an inlet true chord Reynolds number of 250,000 . As the roughness height increases, the transition moves forward, towards the leading edge, for both the suction and pressure surfaces. Only at the highest roughness does the heat transfer appear to be fully turbulent over the entire vane surface. An important feature of these data is that roughness spacing has a very minor effect on heat transfer.

A number of correlations have been proposed to calculate the equivalent sand grain roughness, $k_{\mathrm{S}}$. These correlations show that $k_{\mathrm{S}}$ is strongly dependent on roughness spacing. These correlations for the ratio of $k_{\mathrm{S}}$ to physical height are triangular in shape, with a spacing parameter that gives a maximum ratio. Closely spaced roughness elements are required to achieve the maximum value for $k_{\mathrm{S}}$. Stripf et al.[24] gave $k_{\mathrm{S}}$ values using the correlation of Waigh and Kind[22]. This correlation predicted a strong effect due to spacing, such that the widely spaced roughness would have to have nearly twice the roughness height to achieve the same value for $k_{\mathrm{S}}$. Figure 2 shows that this is inconsistent with the experimental data. The correlation of Sigal and Danberg[17] has three regions, where a plateau separates the two legs of the triangle. At this plateau the ratio of $k_{\mathrm{S}} / k=8$. When applied to roughness measurements of in service blades, a common feature of these correlations is that the roughness image or traces have to be transformed into a model geometry.
Table II. Roughness characteristics

\begin{tabular}{|c|c|c|c|c|c|c|c|c|}
\hline \multirow[t]{2}{*}{ Label } & \multirow[b]{2}{*}{$\mu \mathrm{m}$} & \multirow[t]{2}{*}{$\bar{y}$} & \multirow[t]{2}{*}{$\overline{R_{\mathrm{a}}}$} & \multirow[t]{2}{*}{$R_{\mathrm{RMS}}$} & \multirow[t]{2}{*}{$\overline{S_{\mathrm{k}}}$} & \multicolumn{3}{|c|}{$k_{\mathrm{S}}$} \\
\hline & & & & & & $\begin{array}{r}\text { Waigh \& } \\
\text { Kind } \\
\mu \mathrm{m}\end{array}$ & $\begin{array}{r}\text { Koch \& } \\
\text { Smith } \\
\mu \mathrm{m}\end{array}$ & $\begin{array}{r}\text { Present } \\
\mu \mathrm{m}\end{array}$ \\
\hline $\mathbf{r} 10 \mathrm{~m}$ & 10 & 1.8 & 2.5 & 3.2 & 1.65 & 48 & 15 & 37 \\
\hline $\mathrm{r} 10 \mathrm{~s}$ & 10 & 1.1 & 1.8 & 2.7 & 2.44 & 25 & 11 & 40 \\
\hline r20m & 20 & 3.5 & 5.0 & 6.4 & 1.65 & 96 & 31 & 73 \\
\hline $\mathrm{r} 20 \mathrm{~s}$ & 20 & 2.2 & 3.5 & 5.3 & 2.44 & 51 & 22 & 79 \\
\hline $\mathrm{r} 30 \mathrm{~m}$ & 30 & 5.3 & 7.5 & 9.6 & 1.65 & 144 & 46 & 110 \\
\hline $\mathrm{r} 40 \mathrm{~m}$ & 40 & 7.1 & 10.0 & 12.8 & 1.65 & 192 & 62 & 147 \\
\hline $\mathrm{r} 40 \mathrm{~s}$ & 40 & 3.8 & 6.3 & 10.0 & 2.69 & 89 & 39 & 160 \\
\hline r50s & 48 & 4.0 & 6.7 & 10.8 & 2.87 & 106 & 42 & 181 \\
\hline $\mathrm{r} 80 \mathrm{~m}$ & 80 & 14.1 & 20.0 & 25.5 & 1.65 & 384 & 124 & 293 \\
\hline $\mathrm{r} 80 \mathrm{~s}$ & 80 & 7.6 & 12.7 & 20.0 & 2.69 & 177 & 79 & 320 \\
\hline
\end{tabular}

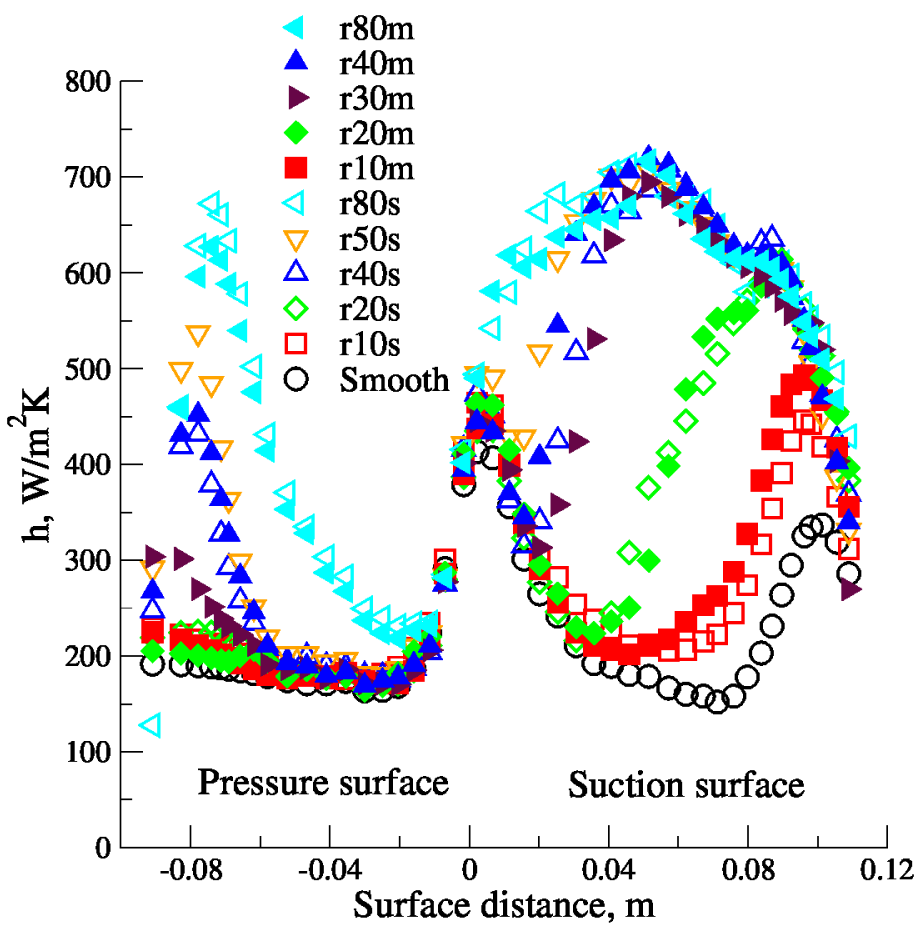

Fig. 2 Heat transfer coefficients, $R e_{\mathrm{IN}}=2.5 \times 10^{5}, T u=$ $8 \%$

The correlation of Koch and Smith[23] uses only a statistical measure of the surface roughness, without requiring that a model geometry be constructed. This correlation gives $k_{\mathrm{S}}=6.2 R_{\mathrm{a}}$. Table II gives statistical quantities $R_{\mathrm{a}}$, $R_{\mathrm{RMS}}$, and skewness $\left(S_{\mathrm{k}}\right)$, of the roughness tested by Stripf et al.[24]. Also shown are $k_{\mathrm{S}}$ values determined from the correlations of Waigh and Kind[22], Koch and Smith[23], and the present proposed correlation. Since the spacing affects the value of $R_{\mathrm{a}}$, the correlation of Koch and Smith[23] shows a spacing effect not seen in the data. Table II also shows that as the spacing increases $R_{\mathrm{a}}$ increases, but the skewness of the roughness decreases. The three statistical quantities given in Table II are defined as:

$$
R_{\mathrm{a}}=\frac{\sum_{\mathrm{i}=1}^{\mathrm{n}}\left|y_{\mathrm{i}}-\bar{y}\right|}{n}
$$

where $n$ equals the number of points in the roughness measurement, and is generally very large. 


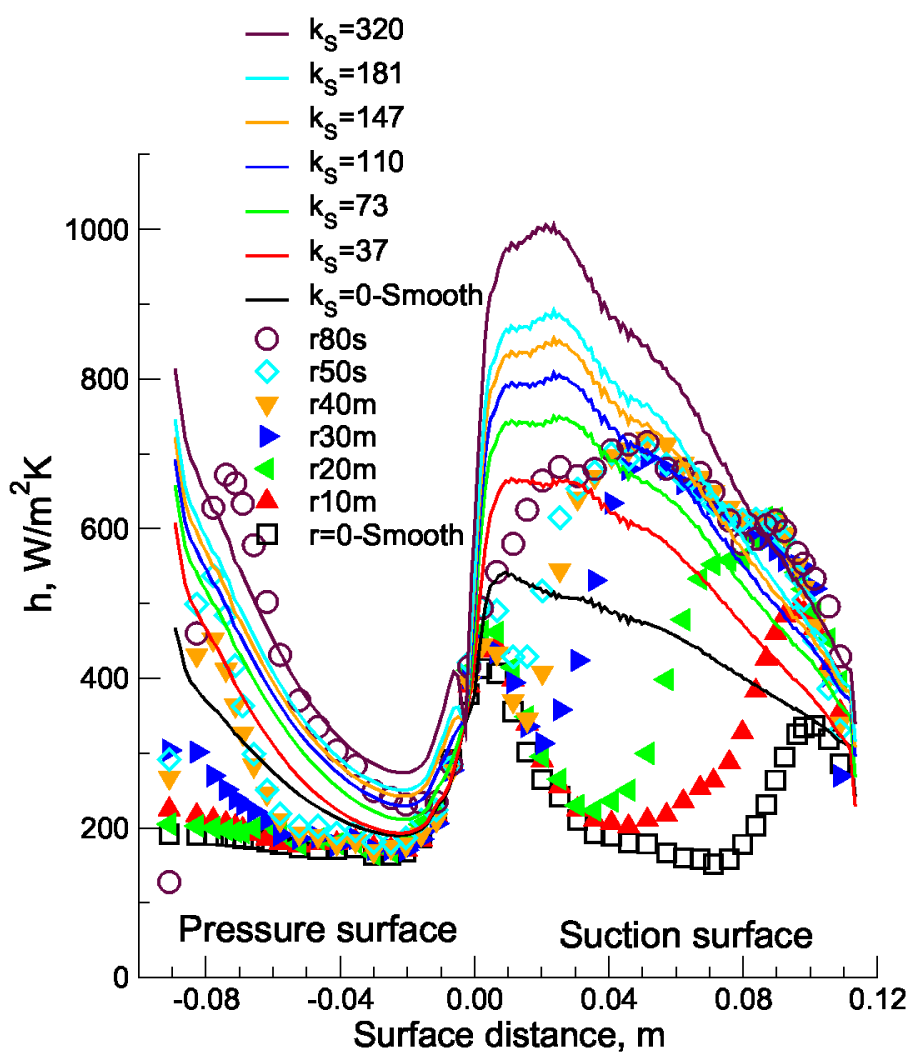

Fig. 3 Comparison of fully turbulent calculations with data. $R e_{\mathrm{IN}}=250,000, T u=8 \%$

$$
R_{\mathrm{RMS}}=\sqrt{\frac{\sum_{\mathrm{i}=1}^{\mathrm{n}}\left(y_{\mathrm{i}}-\bar{y}\right)^{2}}{n-1}}
$$

and

$$
S_{\mathrm{k}}=\frac{\sum_{\mathrm{i}=1}^{\mathrm{n}}\left(y_{\mathrm{i}}-\bar{y}\right)^{3}}{n R_{\mathrm{RMS}}^{3}}
$$

Since the skewness, $S_{\mathrm{k}}$, is related to $R_{\mathrm{RMS}}$, the Koch and Smith [23] correlation was modified to give a $k_{\mathrm{S}}$ consistent with the data shown in figure 2 . The revised correlation for $k_{\mathrm{S}}$ is:

$$
k_{\mathrm{S}}=4.3 R_{\mathrm{RMS}}\left(1+C_{\mathrm{SK}} S_{\mathrm{k}}\right) \quad \text { for } \mathrm{S}_{\mathrm{k}}>0
$$

The coefficient of 6.2 was reduced to 4.3 based on the ratio of $R_{\mathrm{a}}$ to $R_{\mathrm{RMS}}$. The data in figure 2 and the statistics in Table II suggest that $C_{\mathrm{SK}}$ is slightly less than one. However, for simplicity the constant $C_{\mathrm{SK}}$ was set to 1.0. The requirement that $S_{\mathrm{k}}>0$ is not expected to be a difficulty. The measurements of Taylor[25] for the roughness of in service blades showed positive skewness for many cases. Bons et al.[26] measured vane surface roughness, and, except for spalled regions, generally found positive skewness values. Spalled regions gave negative skewness. A conservative approach would be to take $k_{\mathrm{S}}$ as the maximum of $k_{\mathrm{S}}=4.3 R_{\mathrm{RMS}}\left(1+S_{\mathrm{k}}\right)$, Koch and Smith[23] criterion of $k_{\mathrm{S}}=6.2 R_{\mathrm{a}}$, or $k_{\mathrm{S}}=4.3 R_{\mathrm{RMS}}$.

The reasonableness of this correlation is shown in figure 3 where the data shown in figure 2 are compared with fully turbulent calculations for several different equivalent sand grain roughness heights using the above expression for $k_{\mathrm{S}}$. Since the calculations are for fully turbulent flow, comparisons are meaningful only after transition is complete. Overall, the agreement in this region is good. The comparison for the highest roughness, where the measurements indicate nearly fully turbulent flow, shows very good agreement for both the pressure and suction surfaces.

A question which arises from the data in Table II is whether an equivalent roughness height of nearly a third of a millimeter is too high compared to actual measurements. Most data in the literature gives the roughness height in terms of $R_{\mathrm{a}}$, and for comparison with Table II entries the Koch and Smith conversion to $k_{\mathrm{S}}$ will be used. Tarada and Suzuki[27] reported a wide variation in $R_{\mathrm{a}}$ values. They were between 25 and $150 \mu \mathrm{m}$, ( $k_{\mathrm{S}}$ between 155 and $930 \mu \mathrm{m}$ ), and depended on the engine's operating environment. Taylor[25] measured $R_{\mathrm{a}}$ values between 2 and $11 \mu \mathrm{m},\left(k_{\mathrm{S}}\right.$ between 12.4 and $68 \mu \mathrm{m}$ ). Bogard et al.[28] extensively measured surface roughness on two vanes. The first had $R_{\mathrm{a}}$ values between 9 and $22 \mu \mathrm{m}$, and the second ranged from 21 to $46 \mu \mathrm{m}$. This represents a range of $k_{\mathrm{S}}$ between 56 and $285 \mu \mathrm{m}$. Bons et al.[26] measured surface roughness on a variety of turbine blades. For deposition and corrosion they measured $R_{\mathrm{a}}$ values between 3 and $33 \mu \mathrm{m}$, giving a $k_{\mathrm{S}}$ range between 19 and $205 \mu \mathrm{m}$. Zhang and Ligrani[29] calculated a $k_{\mathrm{S}}$ value of $62 \mu \mathrm{m}$ for a turbine blade used in a utility power application. Just in terms of roughness height, the answer is that a roughness height of nearly a third of a millimeter is not excessive.

When Reynolds number effects are accounted for, even the highest roughness may not be sufficiently high. Bogard et al.[28], in a low Reynolds number experiment, scaled up the measured roughness by a factor of 25 to account for Reynolds number effects. Since the roughness parameter, $H^{+}$, (sometimes referred to as $R e_{\mathbf{k}}$ ), increases almost linearly with unit Reynolds number in turbulent flow regime, engine unit Reynolds numbers should be matched if the roughness height scale factor is one. The data of Stripf et al.[24] were obtained at maximum unit Reynolds number less than typically seen by the first stage vane at takeoff, or in an utility application. On the other hand, the unit Reynolds number decreases in later stages, where roughness transition is more likely to be a factor.

\section{Heat transfer modeling assumptions}

The data in figure 2 clearly show transition occurring for both the suction and pressure surfaces of the vane. The locations for transition are strongly dependent on the roughness height. Three modeling issues with respect to transition were investigated. The first was the start of transition. The second was the length of transition. The third was relaminarization. A number of approaches were examined for each of these modeling issues. Rather than detail all of the approaches taken, the modeling that gave 
the best agreement with all of the data is presented.

Start of transition. For the start of transition Mayle's[30] transition start model was modified to account for roughness effects. In this model when the momentum thickness Reynolds number, $R_{\theta}$, exceeds a critical Reynolds number, $R e_{\mathrm{CRIT}}$, transition begins. For smooth surfaces $R e_{\text {CRIT }}=400 T u^{-0.625}$. The critical Reynolds number for rough surface transition is:

$$
R e_{R O U G H}=\frac{R e_{S M O O T H}}{1+T u^{-0.625}\left(C_{\mathrm{ST}}\left(H^{+}-5\right)\right)^{1.25}}
$$

Unless stated otherwise $C_{\mathrm{ST}}=0.05 . H^{+}$is calculated from $H^{+}=k_{\mathrm{S}} U_{\mathrm{FS}} \rho \sqrt{C_{\mathrm{f}} / 2} / \mu$ The term $H^{+}-5$ occurs because a surface roughness that gives $H^{+}$less than 5 is considered hydraulically smooth. Comparisons are made for two inlet turbulence intensities, and including the term $T u^{-0.625}$ gave better agreement with data. This term means that at high $\mathrm{H}^{+}$values, the start of transition is independent of the local turbulence intensity. The roughness term was raised to the 1.25 power based on comparisons with the data, which show suction surface transition moving from near the trailing edge to near the leading edge as the roughness height increases by a factor of eight.

The local turbulence intensity used in the transition start criteria was calculated using the work of Steelant and Dick[31], where the local $T u$ is calculated from:

$$
T u=T u_{\mathrm{IN}}\left(U_{\mathrm{IN}} / U_{\mathrm{FS}}\right)^{3 / 2}
$$

Calculations of the turbulence distribution within the vane passage using a $k-\omega$ turbulence model was consistent with this approximation for the local turbulence intensity when the inlet length scale used in the calculations was small, Because of the accelerations through the vane passage, the maximum local turbulence intensity at the start of transition for the smooth vane was less than one percent. The data showed that this low turbulence intensity in the transition criteria was appropriate.

Transition length. In the base cases the transition length model was not modified to account for roughness effects. When modifications were made the spot production parameter, $N$, was increased by:

$$
N_{\mathrm{ROUGH}}=N_{\mathrm{SMOOTH}} \times \exp \left(C_{\mathrm{LT}}\left(H^{+}-5\right)\right)
$$

With $C_{\mathrm{LT}}=0$ there is no modification to the transition length. The transition length model is the one detailed by Boyle and Simon[32]. It is a modification of the transition length model of Solomon et al.[33] to account for Mach number effects. It was shown to give good agreement with smooth blade heat transfer data for both stator, (Arts et al.[1] and Hylton et al.[34]), and rotor test cases, (Arts et al.[35]). It was found that the length of transition, as evidenced by the rough surface heat transfer data, was reasonably well predicted for many, but not all, cases without modifying the spot production parameter, $N$.

Relaminarization. Because much of the comparisons are at flow conditions where the favorable pressure gradients are strong enough to cause relaminarization, it was necessary to modify the relaminarization criteria. For smooth surfaces it is accepted that when the pressure gradient parameter, $K$, exceeds $3 \times 10^{-6}$ a turbulent boundary will relaminarize. Since data show that as the height of the roughness increases, the laminar pressure surface boundary layer becomes turbulent sooner. Calculations without a relaminarization model showed early pressure surface transition for many cases. The calculation of the critical value of $K$ for relaminarization is:

$$
\left(K_{C R I T}\right)_{R O U G H}=\frac{\left(K_{C R I T}\right)_{S M O O T H}}{\exp \left(-C_{\mathrm{RLM}}\left(H^{+}-5\right)^{1.25}\right)}
$$

where $C_{\mathrm{RLM}}=0.0354$, and $\left(K_{C R I T}\right)_{S M O O T H}=3.0 \times$ $10^{-6}$. The local value for $K$ is calculated from the the local inviscid velocity gradient as:

$$
K=\frac{\nu}{U_{\mathrm{FS}}^{2}} \frac{d U_{\mathrm{FS}}}{d S}
$$

where $S$ is the streamwise distance from the stagnation point.

Heat transfer calculations. Comparisons are made with midspan heat transfer data, so that a two dimensional analysis is appropriate. Heat transfer and loss calculations were done using a quasi-3d Navier Stokes analysis. The solver used was the quasi-3D Navier-Stokes code RVCQ3D, run as a two dimensional analysis. This code has been documented by Chima [36]. C-type grids, typically $377 \times 55$, were used. Boyle and Simon[32] give a more detailed description of the analysis. The solutions were monitored to assure that convergence was achieved.

An algebraic turbulence model described by Chima et al.[37] was used. It is a two layer model, and incorporates the Cebeci-Chang roughness model described in reference 38. This model increases the mixing length to account for roughness. The distance increment is given by:

$$
\Delta y^{+}=0.9\left(\sqrt{H^{+}}-H^{+} e x p^{-0.167 H^{+}}\right)
$$

and

$$
\Delta y=\Delta y^{+} \mu /\left(U_{\mathrm{FS}} \rho \sqrt{C_{f} / 2}\right)
$$

In the algebraic models the increment in $y$ is only applied in the inner region. The turbulent eddy viscosity in the inner region, $\mu_{\mathrm{t}, \mathrm{i}}$ is given by:

$$
\mu_{\mathrm{t}, \mathrm{i}}=\rho(d U / d y)\left[\kappa(y+\Delta y)\left(1-\exp ^{-\left(y^{+}+\Delta y^{+}\right) / A^{+}}\right)\right]^{2}
$$




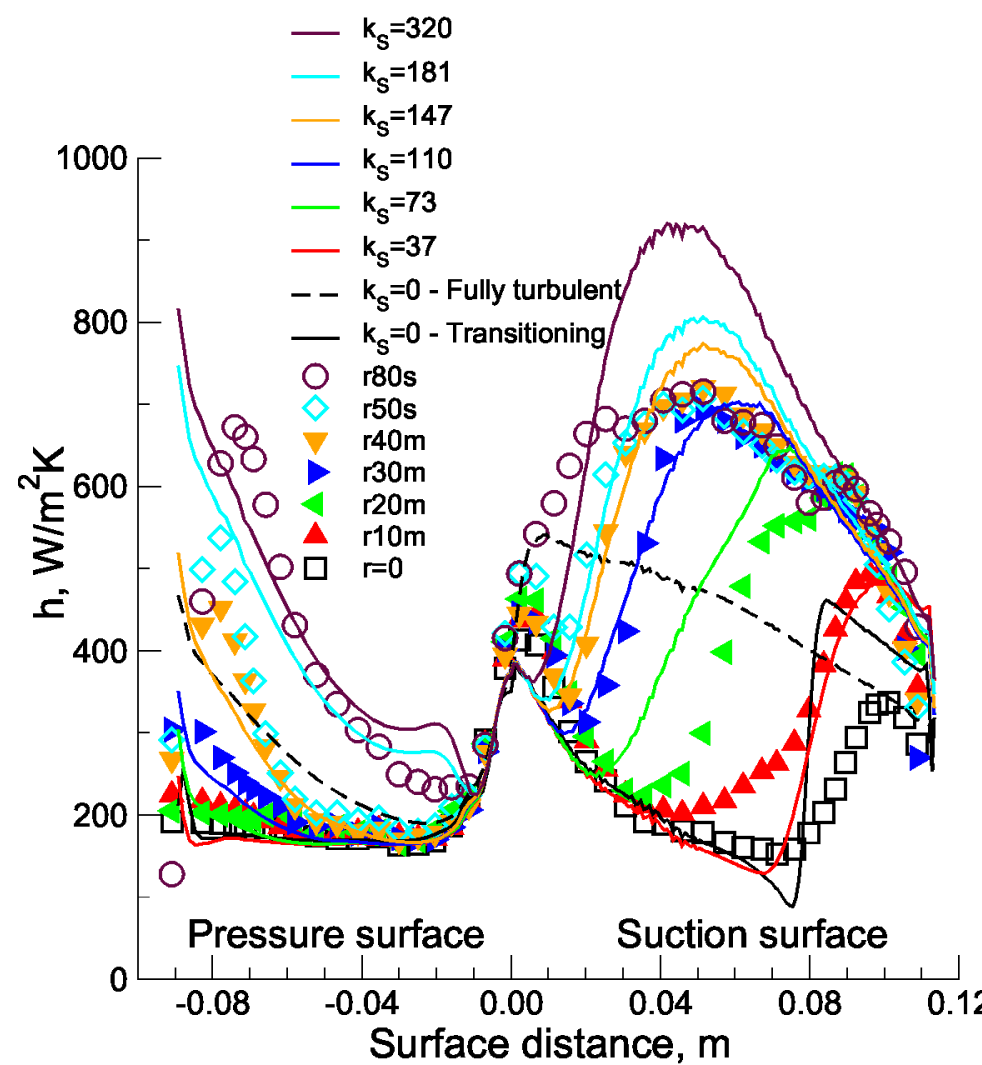

a) $T u_{\mathrm{IN}}=8 \%$

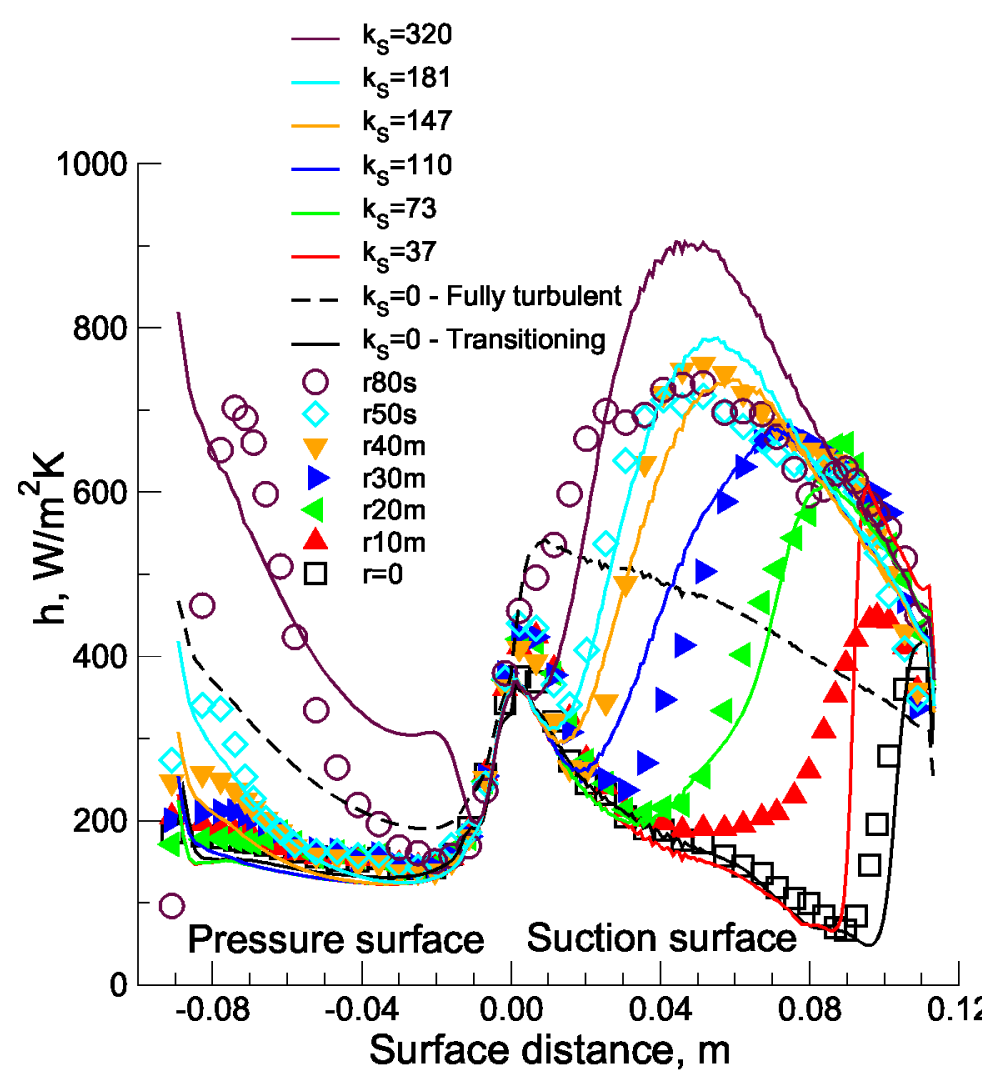

b) $T u_{\mathrm{IN}}=4 \%$

Fig. 4 Transition modeling predictions, $R e_{\mathrm{IN}}=250,000$
In the two equation $k-\omega$ turbulence model roughness effects are accounted for by modifying the wall boundary condition on $\omega$. Two equation models are most applicable when flows are turbulent. Calculations were done using the $k-\omega$ turbulence model only for fully turbulent cases. Calculations using the $k-\omega$ model were similar to those shown in figure 3 , using the algebraic model. For each $k_{\mathrm{S}}$ value the increase in heat transfer over the smooth calculation was nearly the same for both turbulence models.

When the flows were predicted to not be fully turbulent, the laminar viscosity was increased to account for the effects of high freestream turbulence. Ames et al.[39] described two turbulence models to augment laminar viscosity. Based on the results presented by Boyle et al.[40], the Ames model without a leading edge correction was used.

\section{Baseline heat transfer comparisons.}

In this section heat transfer comparisons are made with the cases used to determine the rough surface heat transfer modeling. In a subsequent section comparisons are shown for cases that were not used to determine the transition modeling. The models for rough surface transition and relaminarization have only a few parameters. The number is far less than the number of cases that will be shown in this section. The goal of the work is reasonable agreement for a wide range of cases. Because of the large number of cases, and the small number of parameters, it is unreasonable to expect perfect agreement for all cases.

Comparisons of predicted and measured heat transfer coefficients are given for three Reynolds numbers and two inlet turbulence intensities. Figure 4 compares predicted and measured heat transfer coefficients for an inlet true chord Reynolds number of 250,000 at inlet turbulence intensities of 4 and 8 percent. Since the transition modeling uses only a few parameters, it is note worthy that the agreement for the start of transition is good over the entire range of roughness heights. The agreement is reasonable for both the suction and pressure surfaces, where the streamwise pressure gradients are very different. The second highest roughness shows transition close to the leading edge for the suction surface, but nearly half way back on the pressure surface.

The analysis under predicts the heat transfer in the leading edge region. However, the predictions are in good agreement with pressure surface data, where the flow is laminar. The under prediction in the leading edge region is not due to roughness. Here the analysis under predicts the smooth surface heat transfer by more than the small increase in heat transfer due to roughness.

Figure 4 also shows a fully turbulent calculation for a smooth vane. The data show that the heat transfer rates for the highest roughness can be nearly twice as great as those calculated using the smooth fully turbulent assumption. However, at low to moderate roughness, a fully turbulent calculation can significantly overestimate the heat transfer rate. 
Comparing figures $4 \mathrm{a}$ and $4 \mathrm{~b}$ shows that the heat transfer distributions do not change significantly, even when the turbulence level doubles. The critical Reynolds number for the start of smooth surface transition decreases by nearly fifty percent when the turbulence level doubles. By multiplying the roughness term for the start of transition by a turbulence intensity factor, the agreement with data is improved. However, pressure surface transition at the highest roughness is predicted to occur further downstream than the data. This suggests that the exponent on the $T u$ term in the denominator for the start of transition should be more negative.

The question of whether the transition length correlation should be modified to account for roughness is complicated by the failure of the transition model to accurately predict smooth surface transition. For the smooth vane suction surface transition occurs in regions where the pressure gradient is very negative. At this Reynolds number the pressure gradient at the start of transition for the smooth surface is more negative than the pressure gradient data of Gostelow et al.[41], which was used by Solomon et al.[33] to determine the value of the spot production parameter, $N$. The length of transition is very sensitive to negative pressure gradients. Figure 4a shows that an abrupt smooth suction surface transition was calculated for the $8 \%$ turbulence level. The transition length would increase if $N$ were limited to a smaller value. The data of Gostelow and Walker [42] strongly indicate that extrapolating the correlation of Gostelow et al.[41] to more negative pressure gradients would overestimate the value for $N$. At the lower turbulence intensity, figure $4 \mathrm{~b}$, the start of suction surface transition is at an even more negative pressure gradient, because the critical Reynolds number for the start of transition is increased. At the lower pressure gradient the rapid increase in intermittency is appropriate. Fortunately, the question of whether the transition model should be modified to account for surface roughness is not dependent on extrapolating the database for the correlation of $N$. Where rough surface transition is seen for negative pressure gradient values, they are within the database used to correlate $N$. The form of the correlation for $N$ is asymptotic for large positive values of the pressure gradient.

Figure 5 shows the heat transfer comparisons for a lower inlet Reynolds number of 140,000 for the same two inlet turbulence intensities. Here the analysis shows the same trends as the data, and overall is in reasonably good agreement with the data. Transition is predicted somewhat earlier than is seen in the data, especially at the higher $T u_{\mathrm{IN}}$. Improved agreement with the data would be achieved by changing the coefficient in the transition start model, $C_{\mathrm{ST}}$, from 0.05 to 0.033 . However, the agreement with the data in figure 4 for the higher Reynolds number would not be as good.

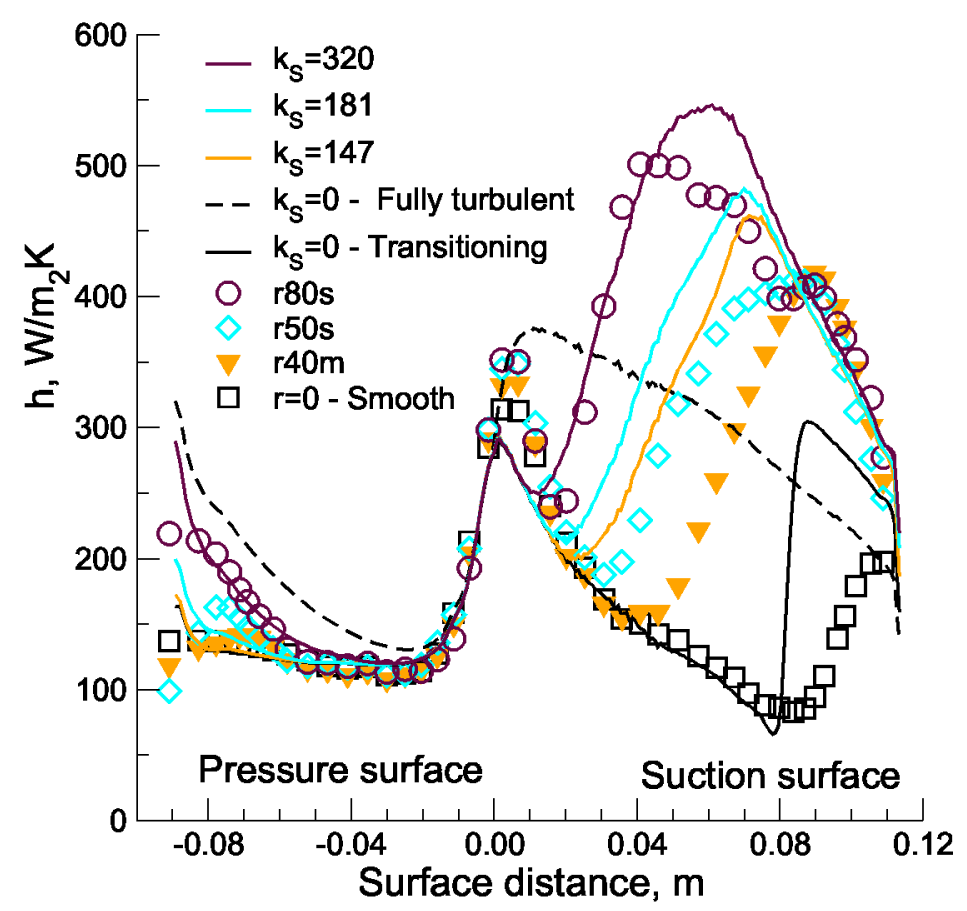

a) $T u_{\mathrm{IN}}=8 \%$

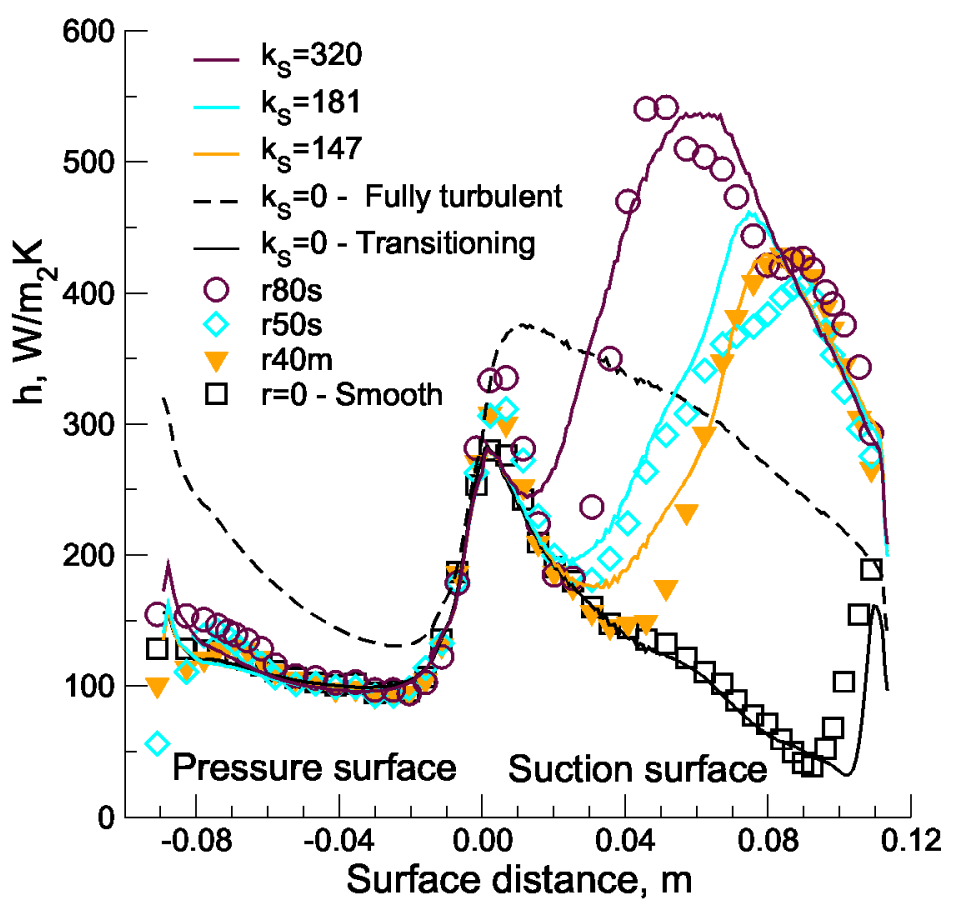

b) $T u_{\mathrm{IN}}=4 \%$

Fig. 5 Transition modeling predictions, $R e_{\mathrm{IN}}=1.4 \times 10^{5}$ 
Table III. Roughness characteristics for Blair's rotor

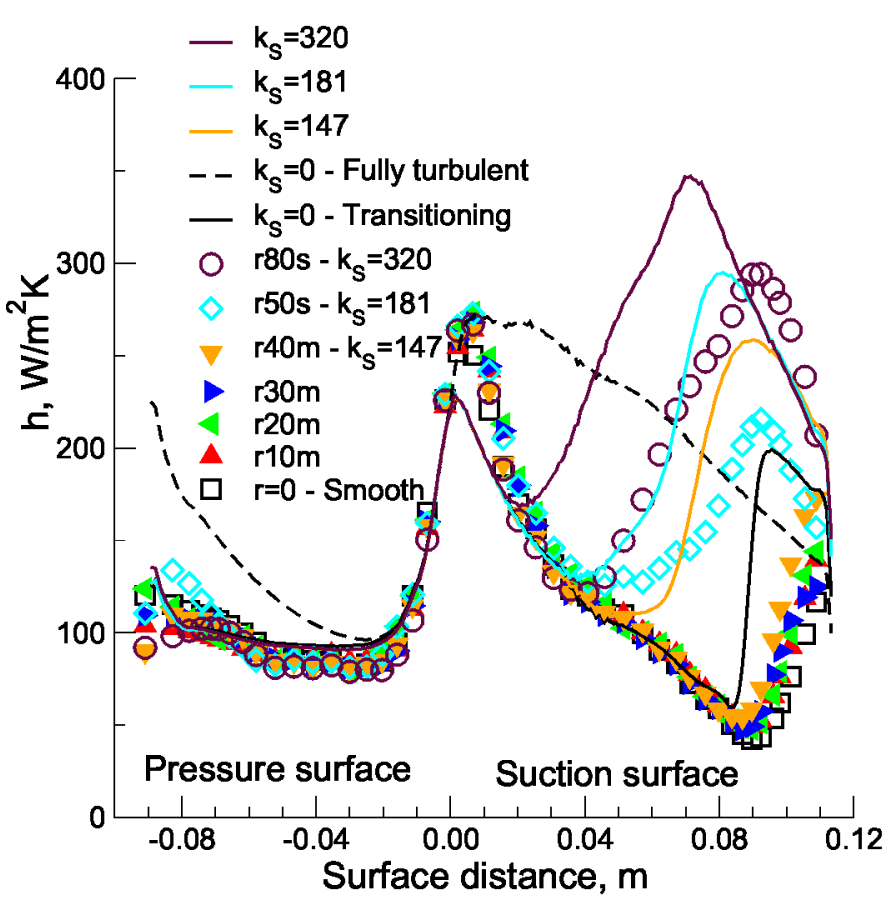

Fig. 6 Transition modeling predictions, $R e_{\mathrm{IN}}=0.9 \times$ $10^{5}, T u_{\mathrm{IN}}=8 \%$

Figure 6 shows the heat transfer comparisons for the lowest inlet Reynolds number of 90,000 . The comparison is at a turbulence intensity of $8 \%$. The agreement is very similar to that in figure 5 for the intermediate roughness. The results in figures 5 and 6 indicate the 1.25 exponent on roughness term should be increased. However, when this was done, either in isolation or in combination with changing the coefficient, $C_{\mathrm{ST}}$, in the transition start model, overall agreement with data was not improved.

\section{Other rough surface heat transfer comparisons.}

Heat transfer comparisons were made for three other data sets, which were not used to deterine the modeling for transition. Each data set shows transition behavior in the heat transfer results.

Turbine rotor of Blair[43]. Figure 7 compares Stanton number predictions with those measured by Blair[43] at the midspan of a turbine rotor. Data was obtained in a large scale rotating turbine test facility. Figure 7 shows comparisons at the highest inlet Reynolds number of 580,000. Stanton numbers were given for a smooth surface, a near smooth surface, and a rough surface. Table III shows the roughness measurements from the reference both as absolute numbers, and as a fraction of axial chord. Only $R_{\mathrm{RMS}}$ and the maximum-to-minimum roughness heights were given. At this Reynolds number the smooth data show that the pressure surface is laminar. The predictions for the smooth suction surface are lower than the data. The inlet turbulence intensity was estimated to be $5 \%$.

\begin{tabular}{|l|c|c|c|}
\hline Label & $\begin{array}{c}R_{\mathrm{RMS}} \\
\mu \mathrm{m}\end{array}$ & $\begin{array}{c}\boldsymbol{R}_{\mathrm{MAX}-\text { to-MIN }} \\
\mu \mathrm{m}\end{array}$ & $\begin{array}{c}\boldsymbol{R}_{\mathrm{MAX}-\text { to-MIN }} / C_{\mathrm{x}} \\
\%\end{array}$ \\
\hline Smooth & 0.33 & 7.6 & 0.0047 \\
Near smooth & 6.4 & 51 & 0.032 \\
Rough & N. A. & 660 & 0.41 \\
\hline
\end{tabular}

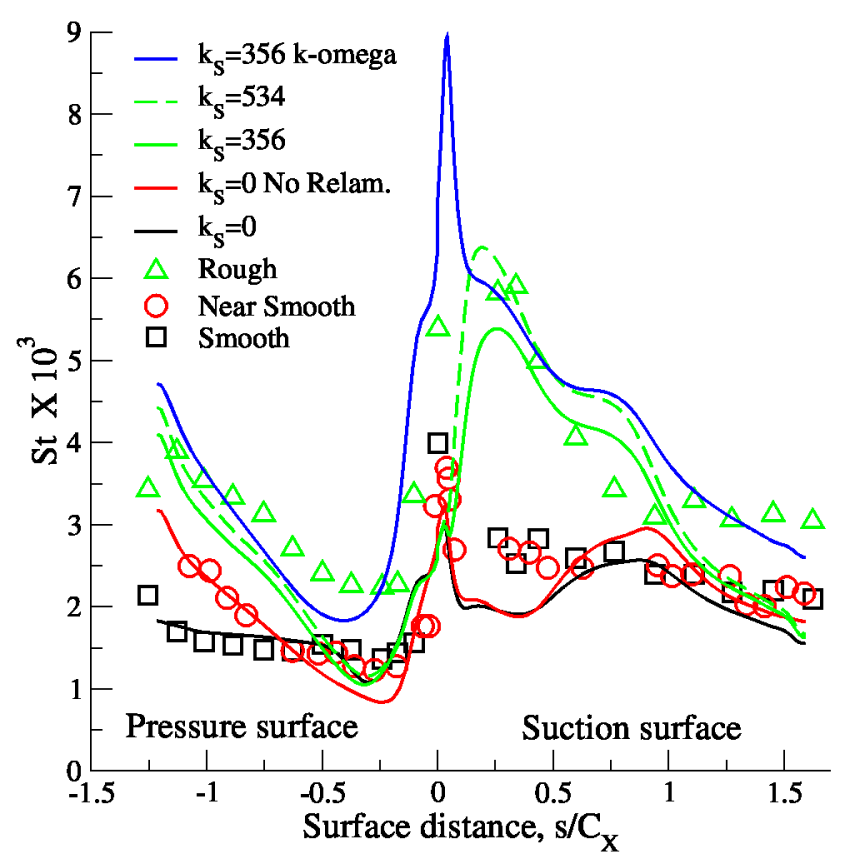

Fig. 7 Comparison with rotor data of Blair[43]

Increasing $T u_{\mathrm{IN}}$ improved agreement for the smooth suction surface, but increased pressure surface heat transfer.

The near smooth data showed transition occurring midway along the pressure surface. A $k_{\mathrm{S}}$ of 27 gave $\mathrm{H}^{+}$ values less than 5 , so that the predicted heat transfer did not change from the smooth surface prediction. Since increased heat transfer is seen in the data, $k_{\mathrm{S}}>4.3 R_{\mathrm{RMS}}$ should have been used. Perhaps the near smooth roughness had positive skewness. Interestingly, good agreement with the near smooth data is achieved when relaminarization is suppressed.

The rough surface data and predictions show that transition occurred close to the leading edge. The rough surface $k_{\mathrm{S}}$ value was estimated using the near smooth $R_{\mathrm{RMS}}$ value and the ratio of maximum to minimum heights. Clearly, this is a some what crude approximation. Nevertheless, the agreement is reasonably good, and improves when $k_{\mathrm{S}}$ is increased by $50 \%$. A prediction is also shown using the k-omega turbulence model. Except for the leading edge region, these results agree well with the data, and are an improvement for the rear portion of the suction surface. 
Table IV. Rough vane roughness characteristics.

\begin{tabular}{|r|c|c|r|c|}
\hline Trace & $\begin{array}{c}R_{\mathrm{RMS}} \\
\mu \mathrm{m}\end{array}$ & $\begin{array}{c}R_{\mathrm{a}} \\
\mu \mathrm{m}\end{array}$ & Skewness & $\begin{array}{c}k_{\mathrm{S}} \\
\mu \mathrm{m}\end{array}$ \\
\hline 1 & 17.7 & 14.0 & 0.206 & 92 \\
2 & 20.5 & 15.9 & -0.441 & 99 \\
3 & 17.5 & 13.9 & -0.010 & 86 \\
4 & 17.0 & 13.0 & -0.085 & 81 \\
\hline Avg. & 18.2 & 14.2 & & 88 \\
\hline
\end{tabular}

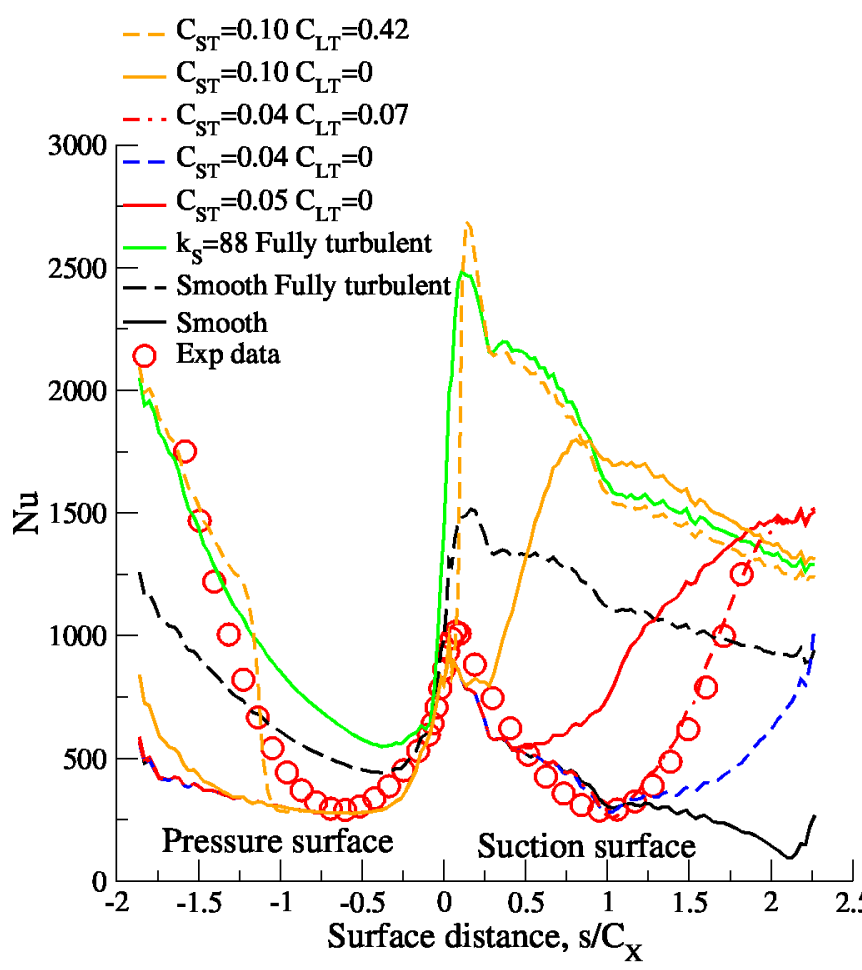

Fig. 8 Comparison with vane data of Boyle and Senyitko[44]

Turbine vane of Boyle and Senyitko[44]. Figure 8 compares measured and predicted Nusselt numbers for the data of Boyle and Senyitko[44]. The roughness characteristics for four measurements are given in Table IV. Calculations were done with $k_{\mathrm{S}}=88 \mu \mathrm{m}$. The data in figure 8 clearly show transition occurring midway along both the pressure and suction surfaces. The axial chord was $52 \mathrm{~mm}$. Even though the axial chord Reynolds number is over a million, and the average $R_{\mathrm{RMS}} / C_{\mathrm{X}}$ was 0.00036 , the measured inlet turbulence was only $1 \%$. Figure 8 shows that at this low turbulence intensity smooth surface calculations predicted laminar flow for all of the pressure and suction surfaces. A smooth fully turbulent calculation gave heat transfer rates much greater than seen in the rough surface data over the forward portion of both the suction and pressure surfaces. The fully turbulent rough surface calculation gave heat transfer rates much greater than the data over most of the suction and pressure surfaces. Towards the rear of both surfaces the agreement between the calculations and data is good. This indicates that the $k_{\mathrm{S}}$ value determined from the roughness statistics is appropriate.

Rough surface heat transfer predictions using the baseline value $C_{\mathrm{ST}}=0.05$ showed early suction surface transition, and no pressure surface transition. Decreasing $C_{\mathrm{ST}}$ by $20 \%$ gave good agreement with the start of suction surface transition. The variations of $k_{\mathrm{S}}$ seen in Table IV are about $10 \%$. Decreasing $C_{\mathrm{ST}}$ by $20 \%$ was the equivalent of decreasing $k_{\mathrm{S}}$ by $21 \%$.

Even with $C_{\mathrm{ST}}=0.04$ the calculated suction surface transition length was longer than seen in the data. Increasing $C_{\mathrm{LT}}$ from 0 to 0.071 showed good agreement for the suction surface transition length. However, this calculation still did not show pressure surface transition consistent with data. A $C_{\mathrm{LT}}=0.42$ was needed to yield pressure surface heat transfer consistent with the experimental data. However, this same calculation gave very poor agreement with the suction surface data, due to rapid transition near the leading edge. The start of transition was not changed. But, suction surface transition began in a region of strong favorable pressure gradients. Consequently, the calculated transition length with $C_{\mathrm{LT}}=0$ was very long.

Turbine blade of Stripf[45]. A second series of tests were run with roughness elements similar to those in the tests used to determine the roughness transition models. Table

$5 \mathrm{~V}$ gives roughness characteristics for the cases. The cases labeled L27a, L27b, and L27c had the same roughness heights, but different spacing between the elements. The different spacings result in different values of the roughness statistics.

Figure 9 compares the measured and predicted heat transfer for this case. Even though these data were not used to develop the roughness transition models, the agreement between the calculations and measured data is good. The calculations were done with no modification of the transition length due to roughness. The results indicate that none was needed.

Figure 10 compares results for different roughness spacing. As seen in Table V the proposed correlation for $k_{\mathrm{S}}$ has little variation among the three cases with the same roughness height. The data in figure 10 shows a dependency on roughness spacing. As seen in Table $\mathrm{V}$ the variation of $R_{\mathrm{a}}$ values is consistent with the the experimental data, in that smaller $R_{\mathrm{a}}$ values give lower heat transfer. However, just using $k_{\mathrm{S}}=6.2 R_{\mathrm{a}}$ does not give good agreement with the data. The value of $H^{+}$are too low. 
Table V. Roughness characteristics of LPT blade

\begin{tabular}{|l|r|r|r|r|r|r|r|}
\hline Label & $k$ & $\bar{y}$ & $R_{\mathrm{a}}$ & $R_{\mathrm{RMS}}$ & $S_{\mathrm{k}}$ & \multicolumn{2}{|c|}{$k_{\mathrm{S}}$} \\
\cline { 5 - 8 } & & & & & & $\begin{array}{r}\text { Koch \& } \\
\text { Smith } \\
\mu \mathrm{m}\end{array}$ & $\begin{array}{r}\text { Present } \\
\mu \mathrm{m}\end{array}$ \\
\hline L17 & 17 & 5.2 & 6.1 & 6.9 & 0.83 & 38 & 77 \\
L27a & 27 & 6.8 & 8.6 & 10.0 & 1.12 & 53 & 121 \\
L27b & 27 & 3.0 & 5.0 & 7.5 & 2.42 & 31 & 127 \\
L27c & 27 & 1.7 & 3.1 & 5.8 & 3.54 & 19 & 131 \\
L50a & 50 & 8.0 & 12.5 & 16.8 & 1.84 & 78 & 223 \\
L90 & 90 & 14.7 & 20.8 & 27.0 & 1.74 & 129 & 395 \\
\hline
\end{tabular}

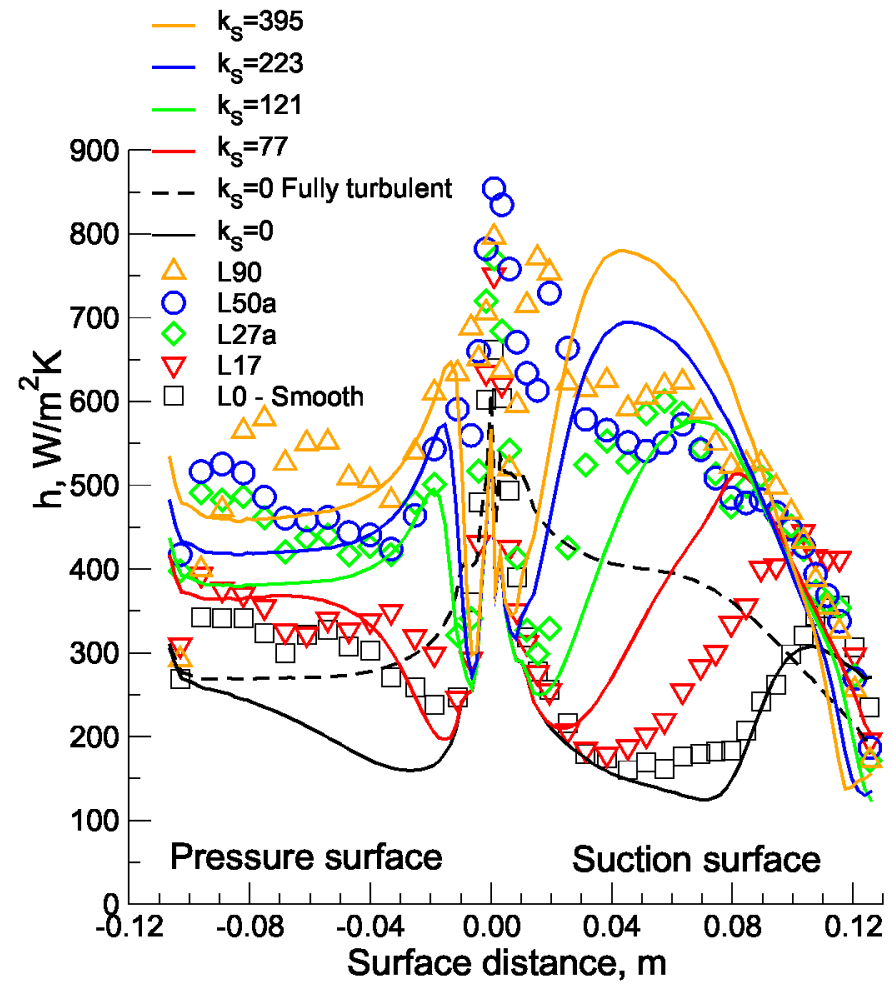

Fig. 9. Comparison with LPT blade data of Stripf[45].

Increasing $C_{\mathrm{ST}}$ from 0.05 to 0.10 to adjust the start of transition when using the Koch and Smith correlation does not give good agreement with the data. It could be argued that a coefficient slightly less than one should be applied to the skewness term. If this is done the coefficients in the roughness models should also be adjusted. Except for specialized test cases, roughness typically exhibits noticeable variations when measured at different blade surface locations.

\section{Extension to higher Reynolds numbers.}

In typical engine applications the Reynolds number may be significantly higher than those used for data comparisons. A series of calculations were done with the same physical roughness, but at a higher Reynolds number. When the Reynolds number was increased, calculations were done for two exit Mach numbers. The lower one, $\left(M_{2}=0.55\right)$, is the same as for the highest Reynolds number tested by Stripf et al.[24]. Since the same geometry

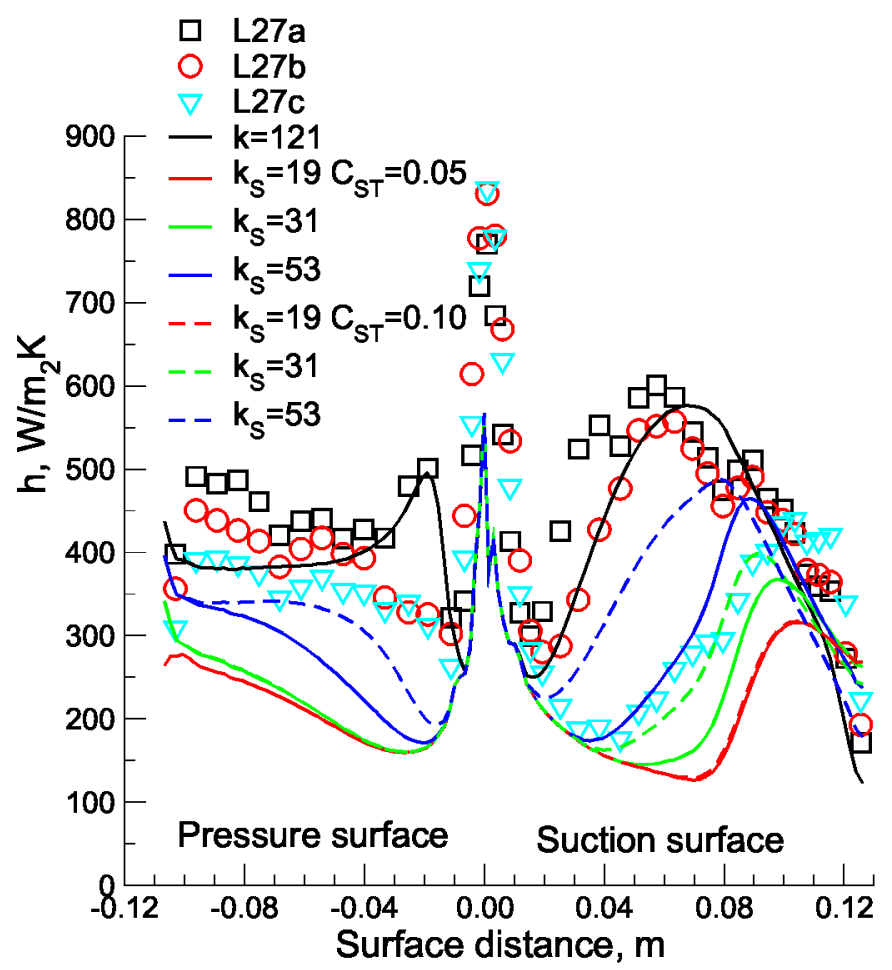

Fig. 10. Effect of roughness spacing on heat transfer.

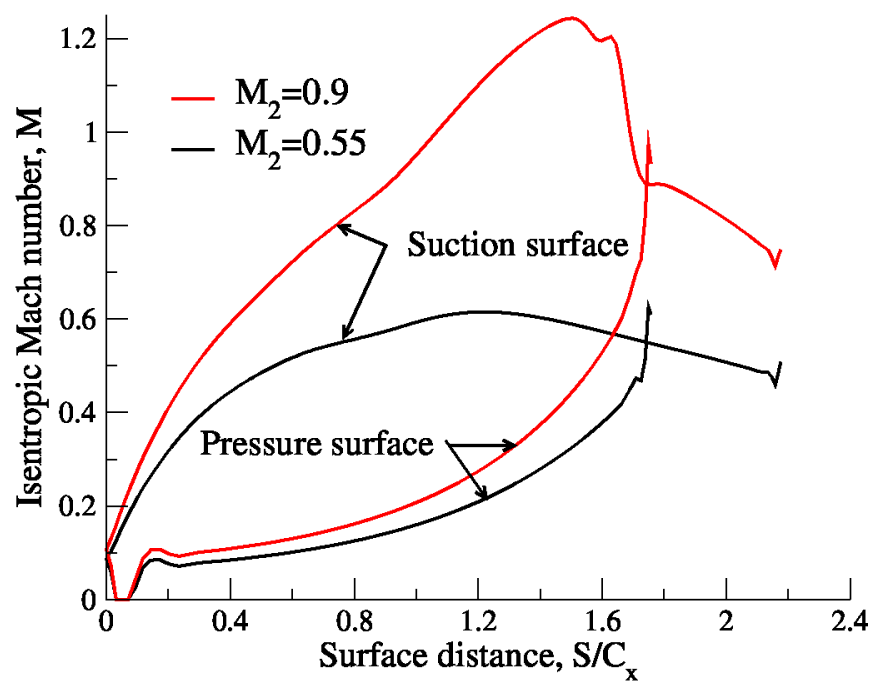

Fig. 11. Mach number distributions.

was used, the vane loading moved aft as the Mach number increased. The vane isentropic Mach number distributions for both exit Mach numbers are shown in figure 11. The higher Mach number results in a very aft loaded vane. This is a consequence of the vane not being designed for this high subsonic Mach number. The results for $M_{2}=0.9$ are presented because the distribution is not unlike the midspan distribution seen when there is an appreciable decrease in the span between the leading and trailing edges. The rapid shock like decrease in Mach number, and consequently rapid diffusion, is a result of the blade profile. 


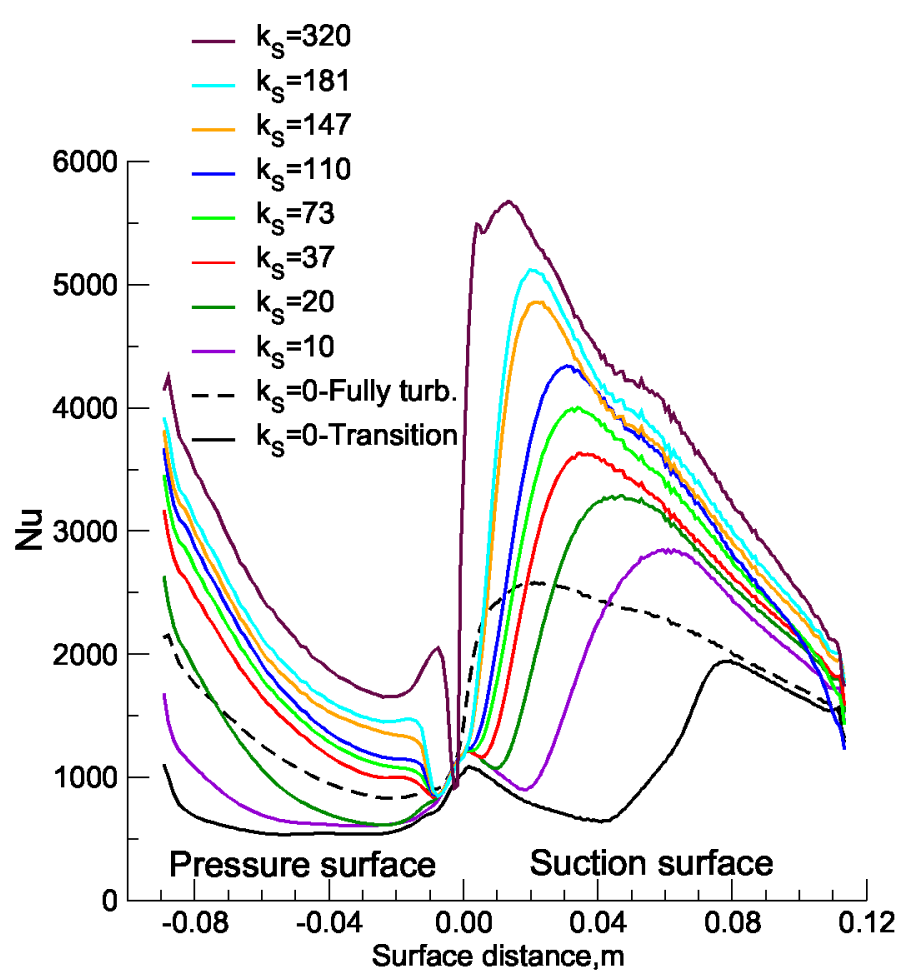

a) $M_{2}=0.55$

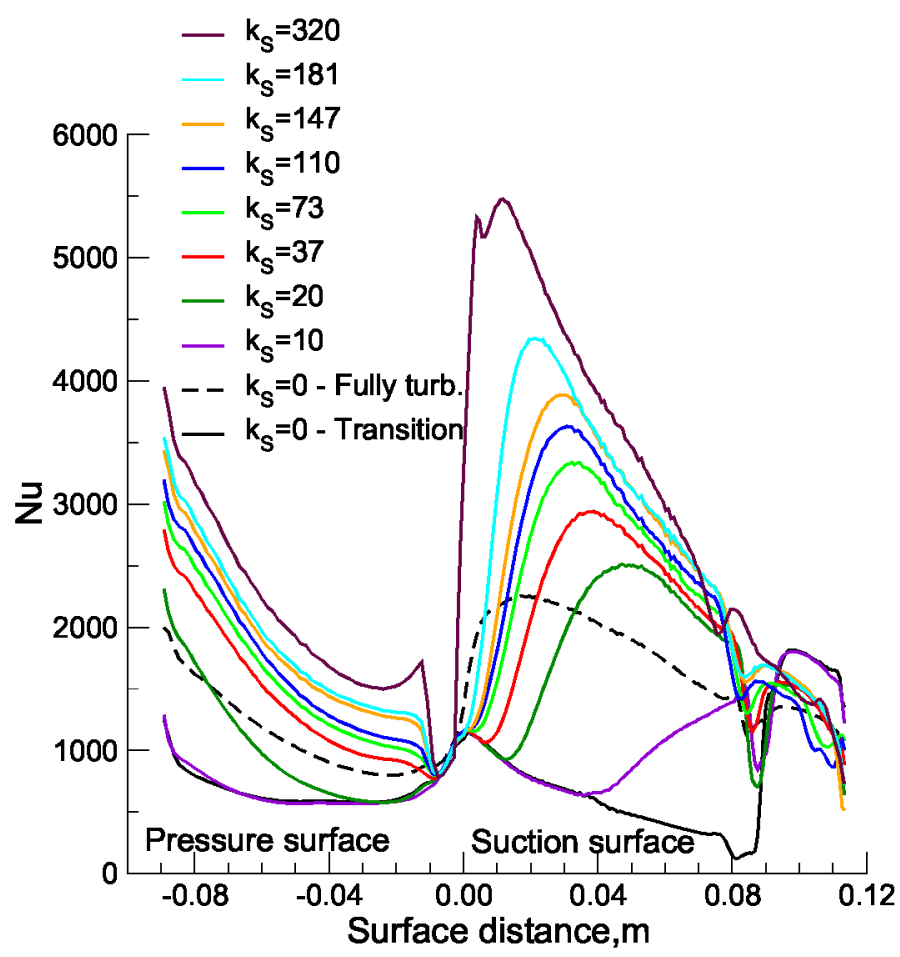

b) $M_{2}=0.9$

Fig. 12 Nusselt numbers at $R e_{1}=300,000 \mathrm{~cm}^{-1}, \mathrm{Tu}=8 \%$

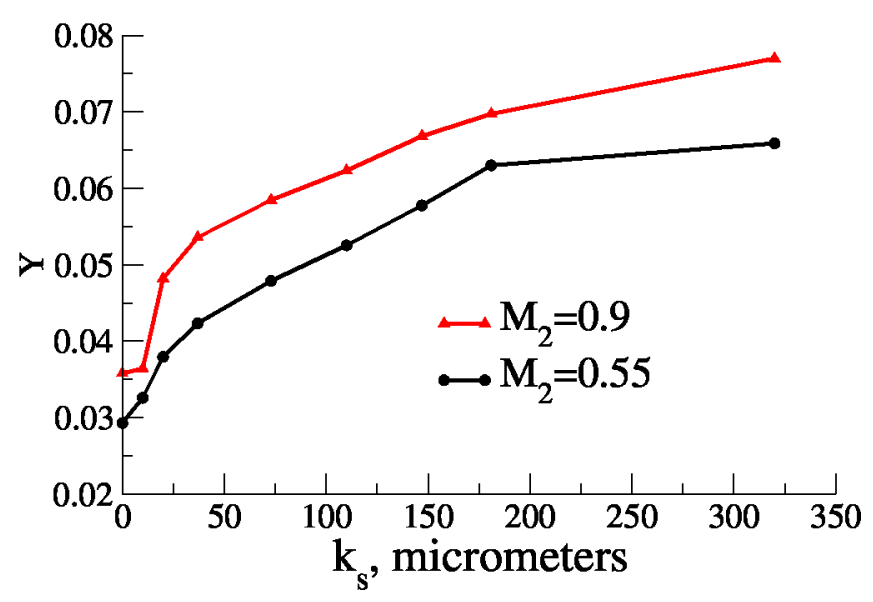

Fig. 13 Calculated losses at $R e_{1}=300,000 \mathrm{~cm}^{-1}$

The axial chord Nusselt number distributions for a range of roughness heights are shown in figure 12 . Nusselt numbers are shown for a vane exit unit Reynolds number of $300,000 \mathrm{~cm}^{-1}$. The value is less than what is typical for a first stage vane of a high pressure turbine. A unit Reynolds number in this range is appropriate for the second stage vane, which may or may not be film cooled. The unit Reynolds number of $300,000 \mathrm{~cm}^{-1}$ is nearly twice as great as the highest Reynolds number tested by Stripf et al.[24]. For the smooth surface, the distance from the leading edge at which suction surface transition is seen nearly doubles as the exit Mach number is increased. This is the result of the aft loading at the higher exit Mach number. At both exit Mach numbers the smooth pressure surface remained almost entirely laminar.

At both exit Mach numbers the effect of increasing surface roughness is to move the location of the start of suction surface transition forward, towards the leading edge. The higher exit Mach number, with the aft loading, shows that a higher $k_{\mathrm{S}}$ value is required for transition to start at the same surface location. Except for the smallest roughness heights, pressure surface transition is very similar at both Mach numbers. Relaminarization is not an issue, and once a critical roughness height is reached, transition to turbulent flow occurs close to the leading edge. For small roughness heights pressure surface transition behaves similar to suction surface transition.

Because the calculations shown in figure 12 are not compared with experimental data, it is useful to relate these results to those presented in the literature in a qualitative manner. This is done to show the reasonableness of the modeling presented herein. Abuaf et al.[8] examined the effects of small roughness on vane heat transfer and aerodynamic efficiency. Their exit vane axial chord Reynolds number varied between $6.8 \times 10^{5}$ and $2.3 \times 10^{6}$. The inlet turbulence intensity was $14 \%$. Their maximum $R_{\mathrm{a}}$ value was $2.33 \mu \mathrm{m}$, but the axial chord was only $4.8 \mathrm{~cm}$. 
The vane was forward loaded, and at the lowest Reynolds number suction surface transition occurred just upstream of the peak isentropic Mach number. Roughness was not a factor in in transition at the lowest Reynolds number. As the Reynolds number increased, the vane with $R_{\mathrm{a}}=2.33 \mu \mathrm{m},\left(k_{\mathrm{S}} \approx 15\right)$, was seen to move transition closer to the leading edge. At the highest Reynolds number transition was seen at the leading edge. Pressure surface transition was not affected by roughness, but was turbulent for nearly $80 \%$ of the surface distance. In the turbulent region the heat transfer rates increased approximately 10 to 15 percent as a result of surface roughness.

The importance of roughness in terms of aerodynamic losses is illustrated in figure 13. The loss coefficient, $Y$ is calculated from:

$$
Y=\frac{P_{\mathrm{IN}, \mathrm{t}}-P_{2, \mathrm{t}}}{P_{\mathrm{IN}, \mathrm{t}}-P_{2}}
$$

Figure 13 shows the loss coefficient, $Y$, as a function of $k_{\mathrm{S}}$. At the highest equivalent height, the loss coefficient nearly doubles, and approaches an asymptotic value. The increase in smooth surface loss for the higher exit Mach number remains even as the surface roughness increases.

The data show that an important parameter is $\mathrm{H}^{+}$. In fully turbulent flow $\mathrm{H}^{+}$is nearly proportional to the Reynolds number. Therefore, doubling the unit Reynolds number results in a similar loss distributions, but with the abscissa in figure 13 reduced by half.

\section{CONCLUDING REMARKS}

An approach to calculating an equivalent sand grain roughness has been given. This approach is consistent with experimental data in that the weak effect of roughness spacing is accounted for. This approach uses only statistical quantities, which are readily available from roughness measurements. When the calculated $k_{\mathrm{S}}$ values were used with either an algebraic or a $k-\omega$ turbulence model, heat transfer rates were in good agreement with data in the fully turbulent regions.

Two-dimensional calculations were done to determine criteria for transition and relaminarization that were reasonably consistent with experimental data. Both calculations and data show heat transfer rates much less than for fully turbulent flow at small roughness heights. For high roughness heights heat transfer rates were nearly double those for the fully turbulent smooth flow. This simplified approach gave reasonable agreement with data for most of the cases examined. There were two prominent exceptions. Both involved the blade pressure surface. The data for the near smooth case of Blair showed that a roughness with a calculated $H^{+}<5$ appeared to cause a laminar boundary to become turbulent. In the second case a vane tested with low inlet turbulence exhibited rapid transition midway along the pressure surface. This was not predicted by the analysis, and further work in this area is needed.

Using the modification to account for roughness on the start of transition, calculations were then done for a unit Reynolds number of $300,000 \mathrm{~cm}^{-1}$. This is representative of the second stage of a high pressure turbine. For good cycle efficiency the second stage vane might not be film cooled, and accurate transition predictions would be important. Vane loading was seen to be an important parameter. Aft loading delayed transition, both for smooth and slightly rough surfaces. Even at this moderately high Reynolds number, smooth and slightly rough surfaces had heat transfer rates significantly less than for the fully turbulent calculations. On the other hand, high roughness levels showed heat transfer rates far greater than those calculated for fully turbulent flow.

The effects of surface roughness on losses were also examined. The smooth aft loaded vane had a greater predicted loss than the forward loaded vane. Loss levels approached asymptotic values nearly twice that of the smooth vane as $k_{\mathrm{S}}$ increased.

\section{REFERENCES}

1. Arts, T., Lambert de Rouvroit, M., and Rutherford, A.W., 1990, "Aero-Thermal Investigation of a Highly Loaded Transonic Linear Turbine Guide Vane Cascade," VKI Technical Note 174.

2. Arts, T., 1995, "Thermal Investigation of a Highly Loaded Transonic Turbine Film Cooled Guide Vane", $1^{\text {st }}$ European Conf. on Turbomachinery - Fluid Dynamic and Thermodynamic Aspects, Erlanger, Germany, also VKI preprint 1995-11.

3. Hourmouziadis, J., 1989, "Aerodynamic Design of Low Pressure Turbines," AGARD Lecture Seris, No. 167

4. Kind, R.J., Serjak, P.J., and Abbott, M.W.P., 1998, "Measurements and Prediction of the Effects of Surface Roughness on Profile Losses and Deviation in a Turbine Cascade," ASME Journal of Turbomachinery, Vol. 120, pp. 20-27.

5. Boynton, J.L., Tabibzadeh, R., and Hudson, S.T., 1993, "Investigation of Rotor Blade Roughness Effects on Turbine Performance," ASME Journal of Turbomachinery, Vol. 115, pp. 614-620.

6. Bammert, K., and Stanstede, H., 1972, "Measurements Concerning the Influence of Surface Roughness and Profile Changes on the Performance of Gas Turbines," ASME Journal of Engineering for Power, Vol. 94, pp. 207-213.

7. Bammert, K., and Stanstede, H., 1976, "Influences of Manufacturing Tolerances and Surface Roughness of Blades on the Performance of Turbines," ASME Journal of Engineering for Power, Vol. 98, pp. 29-36.

8. Harbecke, U.G., Riess, W. and Seume, J.R., 2002, "The Effect of Milling Process Induced Coarse Surface Texture on Aerodynamic Turbine Profile Losses," ASME paper GT-20023033

9. Abuaf, N., Bunker, R.S., and Lee, C.P., 1998, "Effects of Surface Roughness on Heat Transfer and Aerodynamic Performance of Turbine Airfoils," ASME Journal of Turbomachinery, Vol. 120, pp. 522-529. 
10. Stabe, R.G., and Liebert, C.H., 1975, "Aerodynamic Performance of a Ceramic-Coated Core Turbine Vane Tested with Cold Air in a Two-Dimensional Cascade", NASA Report No. $\mathrm{TMX}=3191$.

11. Boyle, R.J., and Senyitko, R.G., 2003, "Measurements and Predictions of Surface Roughness Effects on Turbine Vane Aerodynamics," ASME paper GT-2003-38580

12. Taylor, R.P, Coleman, H.W., and Hodge, B.K., 1985, "Predictions of Turbulent Rough-Wall Skin Friction Using a Discrete Element Approach," ASME Journal of Fluids Engineering, Vol. 107, pp. 251-257.

13. Hosni, M.H., Coleman, H.W., and Taylor R.P., 1991, "Measurements and Calculations of Rough Wall Heat Transfer in the Turbulent Boundary Layer," Int. J. of Heat and Mass Transfer, Vol. 34 pp. 1067-1082.

14. Stripf, M., Schulz, A., and Bauer, H.-J., 2008, "Modeling of Rough Wall Boundary Layer Transition and Heat Transfer on Turbine Airfoils," ASME Journal of Turbomachinery, Vol. 130 pp. 021003-1 - 021003-11.

15. McClain, S.T., 2002, "A Discrete Element Method for Turbulent Flows Over Randomly Rough Surfaces," PhD. thesis, Mississippi State Univ., Missippi state, MS, 39762

16. McClain, S.T., Hodge, B.K., and Bons, J.P., 2003, "Predicting Skin Friction and Heat Transfer for Turbulent Flow Over Real Gas Turbine Surface Roughness Using the Discrete Element Method," ASME paper GT2003-38813

17. Sigal, A., and Danberg, J.E., 1990, "New Correlation of Roughness Density Effect on the Turbulent Boundary Layer," AIAA Journal, Vol. 28, No. 3, pp. 554-556.

18. Dvorak, F.A., 1969, "Calculation of Turbulent Boundary Layers on Rough Surfaces in Pressure Gradient," AIAA Journal, Vol. 7, No. 9, pp. 1752-1759.

19. Simpson, R.L., 1973, "A Generalized Correlation of Roughness Density Effects in the Turbulent Boundary Layer," AIAA Journal, Vol. 11, No. 2, pp. 242-244.

20. Dirling, R.B., 1973, "A Method for Computing Roughwall Heat Transfer Rates on Re-Entry Nosetips," AIAA paper 73763

21. van Rij, J.A., Belnap, B.J., and Ligrani, P.M., 2002, "Analysis and Experiments on Three-Dimensional, Irregular Surface Roughness," ASME Journal of Fluids Engineering, Vol. 124, pp. 671-677.

22. Waigh, D.R., and Kind, R.J., 1998, "Improved Aerodynamic Characterization of Regular Three-Dimensional Roughness," AIAA Journal, Vol. 36, No. 6, pp 1117-1119.

23. Koch, C.C., and Smith, L.H., 1976, "Loss Sources and Magnitudes in Axial-Flow Compressors," ASME Journal of Engineering for Power, Vol. 98, pp. 411-424.

24. Stripf, M. Schulz, A., and Wittig, S., 2005, "Surface Roughness Effects on External Heat Transfer of a HP Turbine Vane," ASME Journal of Turbomachinery, Vol. 127, pp. 200-208.

25. Taylor, R.P., 1990, "Surface Measurements on Gas Turbine Blades," ASME Journal of Turbomachinery, Vol. 112, pp. 175180.

26. Bons, J.P., Taylor, R.P., McClain, S.T., and River, R.B., 2001, "The Many Faces of Turbine Surface Roughness," ASME Journal of Turbomachinery, Vol. 123, pp. 739-748.

27. Tarada, F., and Suzuki, M., 1993, "External Heat Transfer Enhancement to Turbine Blading Due to Surface roughness," ASME Paper No. 93-GT-74.

28. Bogard, D.G., Schmidt, D.L., and Tabbita, M., 1998,
"Characterization and Laboratory Simulation of Turbine Airfoil Surface Roughness and Associated Heat Transfer," ASME Journal of Turbomachinery, Vol. 120, pp. 337-342.

29. Zhang, Q. and Ligrani, P.M., 2004, "Mach Number/Surface Roughness Effects on Symmetric Transonic Turbine Airfoil Aerodynamic Losses," AIAA Journal of Propulsion and Power, Vol. 20, No. 6, pp. 1117-1125.

30. Mayle, R.E., 1991, "The Role of Laminar-Turbulent Transition in Gas Turbine Engines", ASME Journal of Turbomachinery, Vol. 113, pp. 509-537.

31. Steelant, J. and Dick, E., 1999 "Prediction of By-Pass Transition By Means of a Turbulence Weighting Factor - Part I: Theory and Validation," ASME paper 99-GT-29.

32. Boyle, R.J, and Simon, F.F., 1999, "Mach Number Effects on Turbine Blade Transition Length Prediction," ASME Journal of Turbomachinery, Vol. 121, pp. 694-702.

33. Solomon, W.J., Walker, G.J., and Gostelow, J.P., 1996 "Transition Length Prediction For Flows With Rapidly Changing Pressure Gradients", ASME Journal of Turbomachinery, Vol. 118, pp. 744-751.

34. Hylton, L.D., Mihelc, M.S., Turner, E.R., Nealy, D.A., and York, R.F., 1983, "Analytical and Experimental Evaluation of the Heat Transfer Distribution Over the Surfaces of Turbine Vanes," NASA CR-168015.

35. Arts, T., Duboue, J.-M., and Rollin, G., 1997, "AeroThermal Performance Measurements and Analysis of a TwoDimensional High Turning Rotor Blade," ASME paper 97-GT120.

36. Chima, R.V., 1987 "Explicit Multigrid Algorithm for Quasi-Three- Dimensional Flows in Turbomachinery," AIAA Journal of Propulsion and Power, Vol. 3, No. 5, pp. 397-405. 37. Chima, R.V., Giel, P.W., Boyle, R.J., 1993, "An Algebraic Turbulence Model for Three-Dimensional Viscous Flows," AIAA Paper 93-0083, (NASA TM-105931).

38. Cebeci, T., and Chang, K.C., 1978, "Calculation of Incompressible Rough-Wall Boundary Layer Flows," AIAA Journal, Vol. 16, No. 7, pp 730-735.

39. Ames, F.E., Wang, C., and Barbot, P.A., 2003, "Measurement and Prediction of the Influence of Catalytic and Dry Low NOx Combustor Turbulence on Vane Surface Heat Transfer," ASME Journal of Turbomachinery, Vol. 125, pp. 221-231.

40. Boyle, R.J., Giel, P.W., and Ames, F.E., "Predictions for the Effects of Freestream Turbulence on Turbine Blade Heat Transfer," ASME paper GT2004-54332.

41. Gostelow, J.P., Blunden, A.R., Walker, G.J., 1994, "Effects of Free-Stream Turbulence and Adverse Pressure Gradients on Boundary Layer Transition," ASME Journal of Turbomachinery, Vol. 116, pp. 392-404.

42. Gostelow, J.P., and Walker, G.J., 1991, "Similarity Behavior in Transitional Boundary Layers Over a Range of Adverse Pressure Gradients and Turbulence Levels,: ASME Journal of Turbomachinery, Vol. 113, pp. 617-625.

43. Blair, M.F., 1994, "An Experimental Study of Heat Transfer in a Large-Scale Turbine Rotor Passage," ASME Journal of Turbomachinery, Vol. 116, pp. 1-13.

44. Boyle, R.J., and Senyitko, R.G., 2005, "Effects of Surface Roughness on Turbine Vane Heat Transfer," ASME paper GT2005-69133

45. Stripf, M., 2007, "Einfluss der Oberflächenrauigkeit auf die transitionale Grenzschicht an Gasturbinenschaufeln," Forschungsberichte aus dem Institut für Thermische Strömungsmaschinen, 38, Logos, Berlin. (ISBN:978-38325-1805-9) 


\begin{tabular}{|c|c|c|c|c|c|}
\hline \multicolumn{5}{|c|}{ REPORT DOCUMENTATION PAGE } & $\begin{array}{c}\text { Form Approved } \\
\text { OMB No. 0704-0188 }\end{array}$ \\
\hline \multicolumn{6}{|c|}{ 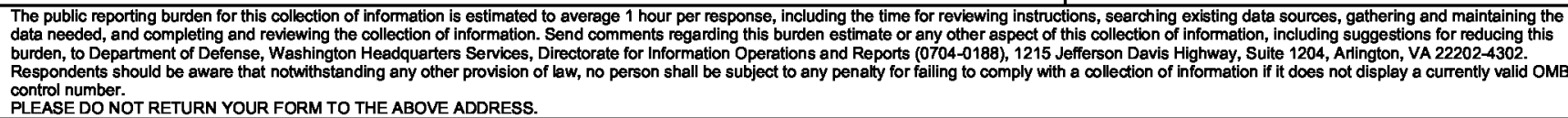 } \\
\hline \multicolumn{2}{|c|}{$\begin{array}{l}\text { 1. REPORT DATE (DD-MM-YYYY) } \\
01-07-2009\end{array}$} & \multicolumn{3}{|c|}{$\begin{array}{l}\text { 2. REPORT TYPE } \\
\text { Technical Memorandum }\end{array}$} & 3. DATES COVERED (From - To) \\
\hline \multirow{3}{*}{\multicolumn{5}{|c|}{$\begin{array}{l}\text { 4. TITLE AND SUBTITLE } \\
\text { Simplified Approach to Predicting Rough Surface Transition }\end{array}$}} & 5a. CONTRACT NUMBER \\
\hline & & & & & 5b. GRANT NUMBER \\
\hline & & & & & 5c. PROGRAM ELEMENT NUMBER \\
\hline \multirow{3}{*}{\multicolumn{5}{|c|}{$\begin{array}{l}\text { 6. AUTHOR(S) } \\
\text { Boyle, Robert, J.; Stripf, Matthias }\end{array}$}} & 5d. PROJECT NUMBER \\
\hline & & & & & 5e. TASK NUMBER \\
\hline & & & & & $\begin{array}{l}\text { 5f. WORK UNIT NUMBER } \\
\text { WBS 561581.02.08.03.21.02 }\end{array}$ \\
\hline \multicolumn{5}{|c|}{$\begin{array}{l}\text { 7. PERFORMING ORGANIZATION NAME(S) AND ADDRESS(ES) } \\
\text { National Aeronautics and Space Administration } \\
\text { John H. Glenn Research Center at Lewis Field } \\
\text { Cleveland, Ohio } 44135-3191\end{array}$} & $\begin{array}{l}\text { 8. PERFORMING ORGANIZATION } \\
\text { REPORT NUMBER } \\
\text { E-17004 }\end{array}$ \\
\hline \multirow{2}{*}{\multicolumn{5}{|c|}{$\begin{array}{l}\text { 9. SPONSORING/MONITORING AGENCY NAME(S) AND ADDRESS(ES) } \\
\text { National Aeronautics and Space Administration } \\
\text { Washington, DC 20546-0001 }\end{array}$}} & $\begin{array}{l}\text { 10. SPONSORING/MONITOR'S } \\
\text { ACRONYM(S) } \\
\text { NASA }\end{array}$ \\
\hline & & & & & $\begin{array}{l}\text { 11. SPONSORING/MONITORING } \\
\text { REPORT NUMBER } \\
\text { NASA/TM-2009-215662 }\end{array}$ \\
\hline \multicolumn{6}{|c|}{$\begin{array}{l}\text { 12. DISTRIBUTION/AVAILABILITY STATEMENT } \\
\text { Unclassified-Unlimited } \\
\text { Subject Category: } 34 \\
\text { Available electronically at http://gltrs.grc.nasa.gov } \\
\text { This publication is available from the NASA Center for AeroSpace Information, 443-757-5802 }\end{array}$} \\
\hline \multicolumn{6}{|c|}{ 13. SUPPLEMENTARY NOTES } \\
\hline \multirow{2}{*}{\multicolumn{6}{|c|}{$\begin{array}{l}\text { 14. ABSTRACT } \\
\text { Turbine vane heat transfer predictions are given for smooth and rough vanes where the experimental data show transition moving forward } \\
\text { on the vane as the surface roughness physical height increases. Consistent with smooth vane heat transfer, the transition moves forward for a } \\
\text { fixed roughness height as the Reynolds number increases. Comparisons are presented with published experimental data. Some of the data } \\
\text { are for a regular roughness geometry with a range of roughness heights, Reynolds numbers, and inlet turbulence intensities. The approach } \\
\text { taken in this analysis is to treat the roughness in a statistical sense, consistent with what would be obtained from blades measured after } \\
\text { exposure to actual engine environments. An approach is given to determine the equivalent sand grain roughness from the statistics of the } \\
\text { regular geometry. This approach is guided by the experimental data. A roughness transition criterion is developed, and comparisons are } \\
\text { made with experimental data over the entire range of experimental test conditions. Additional comparisons are made with experimental heat } \\
\text { transfer data, where the roughness geometries are both regular as well as statistical. Using the developed analysis, heat transfer calculations } \\
\text { are presented for the second stage vane of a high pressure turbine at hypothetical engine conditions. } \\
\text { 15. SUBJECT TERMS } \\
\text { Turbine blades; Heat transfer; Surface roughness; Boundary layer transition }\end{array}$}} \\
\hline & & & & & \\
\hline \multicolumn{3}{|c|}{ 16. SECURITY CLASSIFICATION OF: } & $\begin{array}{l}\text { 17. LIMITATION OF } \\
\text { ABSTRACT }\end{array}$ & $\begin{array}{l}\text { 18. NUMBER } \\
\text { OF }\end{array}$ & $\begin{array}{l}\text { 19a. NAME OF RESPONSIBLE PERSON } \\
\text { STI Help Desk (email:help@sti.nasa.gov) }\end{array}$ \\
\hline $\begin{array}{l}\text { a. REPORT } \\
\text { U }\end{array}$ & $\begin{array}{l}\text { b. ABSTRACT } \\
\text { U }\end{array}$ & \begin{tabular}{|l|} 
C. THIS \\
PAGE \\
U \\
\end{tabular} & UU & $\begin{array}{c}\text { PAGES } \\
19\end{array}$ & $\begin{array}{l}\text { 19b. TELEPHONE NUMBER (Include area code) } \\
443-757-5802\end{array}$ \\
\hline
\end{tabular}



